Article

\title{
What Does the Sustainability-Risk Interaction Look Like? Exploring Nuanced Relationships in Emerging Economy Sustainability Initiatives
}

\author{
Aysu Göçer ${ }^{1, *}$, Stanley E. Fawcett ${ }^{2}$ and Okan Tuna ${ }^{3}$ \\ 1 Department of Logistics Management, Business Faculty, Izmir University of Economics, Sakarya Street, \\ No. 156, Balçova, 35330 İzmir, Turkey \\ 2 Goddard School of Business, Weber State University, Ogden, UT 84408, USA; sfawcett@weber.edu \\ 3 Department of Logistics Management, Maritime Faculty, Dokuz Eylul University, Adatepe District, \\ Doğuş Street, No. 207, Tinaztepe Campus, Buca, 35390 İzmir, Turkey; otuna@deu.edu.tr \\ * Correspondence: aysu.gocer@ieu.edu.tr; Tel.: +90-232-279-2626
}

Received: 11 June 2018; Accepted: 30 July 2018; Published: 2 August 2018

\begin{abstract}
To be viable long-term, sustainability programs must be profitable. Unfortunately, current sustainability practices increase risk, increasing costs and threatening revenues. Higher costs and lower revenues negatively impact profitability and, thus, the viability of sustainability. To understand how sustainability-induced risks affect food production systems, sustainability-induced risks in food production systems are identified and classified. It is also explored how sustainability risks interact, making it especially costly and difficult to eradicate them. An inductive, interview-based method was employed, which relies on 41 semi-structured interviews, with managers at 32 companies. The study documents the interaction between sustainability and risk in five risk categories-behavioral, opportunism, organizational routines, safety and traceability routines and systems design. The negative impact of intensive interactions among these risk categories threatens food production systems' sustainability initiatives. Behavioral risks are particularly pervasive and harmful as they either induce or exacerbate other risk clusters. Elaborating the interaction between sustainability and risk, as well as documenting risk types and interactions, provides a more holistic view of sustainability implementation. This nuanced view will lead to a more accurate and insightful costing of sustainability programs. Lamentably, the most pervasive risk category-i.e., behavioral risks-are often overlooked in the supply chain management literature. However, this research shows a clear need to delve more deeply into the behavioral dimension to improve risk management and to increase the viability of sustainability. This study identifies and categorizes sustainability-induced risk factors in food production systems, and shows how they interrelate, providing the foundation for better planning and execution of viable sustainability programs.
\end{abstract}

Keywords: supply chain; sustainability; risk; food industry; production systems

\section{Introduction}

Sustainability, as articulated by the triple-bottom line [1], is increasingly a strategic imperative [2]. Companies pursue sustainable operations for a variety of motivations. For instance, some companies pursue socially responsible practices because they are the right thing to do, regardless of cost [3]. Most companies, however, pursue sustainability to improve corporate image or enhance operational efficiencies. Sustainability supports competitive strategy by immunizing a firm from reputational risk and reducing operating costs [4-6]. For these companies, integrating environmental, social, and economic concerns is only viable if such efforts provide an economic return [2]. 
This reality means that managers must pursue projects that either reduce costs or increase revenue sufficiently to offset corporate social responsibility (CSR) investments. Carefully assessing the benefits and costs of a firm's sustainability strategies is thus critical to enduring sustainability success [3]. For instance, socially responsible practices are often perceived as insurance against reputational risk [7]. That is, sustainability practices are put in place to mitigate exposure risks (see Figure 1). To the extent that sustainability protects a firm's reputation, the company obtains a valuable benefit.

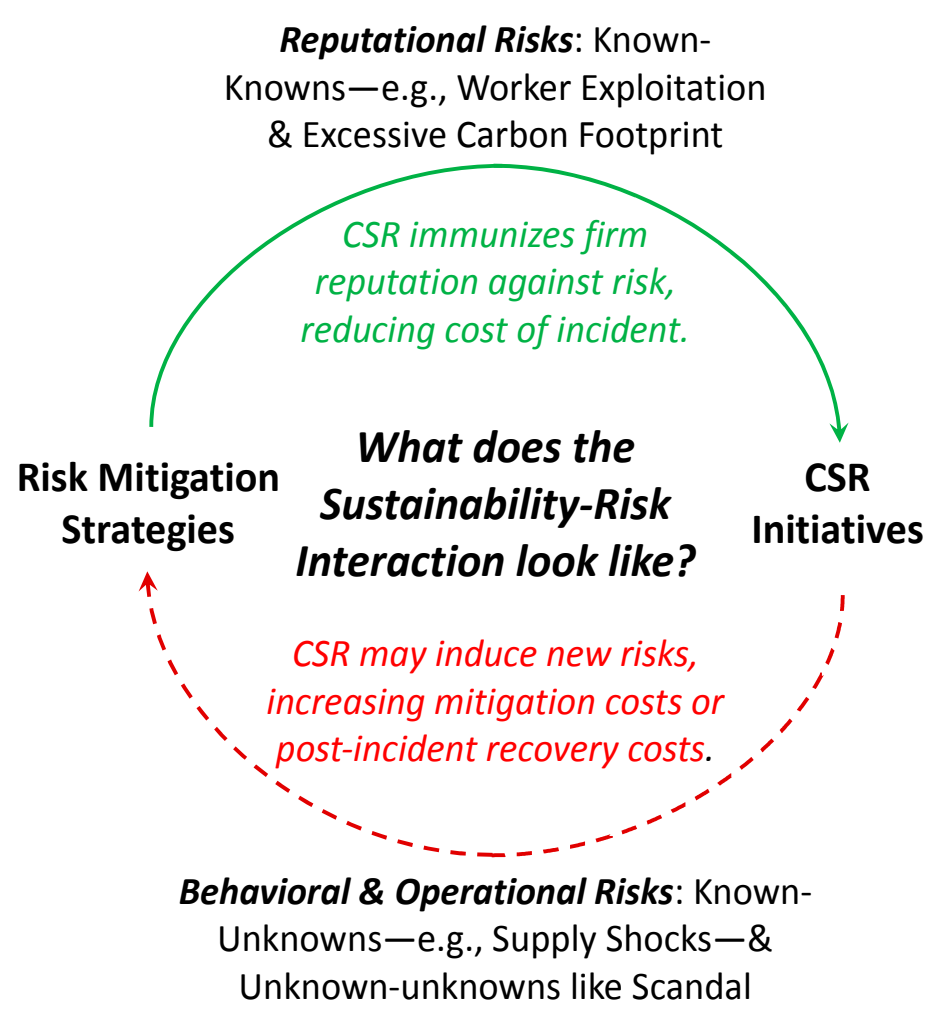

Figure 1. Nuanced, bi-directional sustainability-risk relationship.

However, the sustainability-risk relationship may be more nuanced. Indeed, recent disruptions show that sustainability initiatives can constrain supply options and otherwise increase buyer dependency on supplier behavior and capabilities. Further, a corporate emphasis on sustainability may also induce individual decision-makers to pursue deceptive practices (e.g., Volkswagen's Dieselgate scandal). When disruptions like these occur, sustainability may induce unexpected risks, increasing costs, and potentially leading to financial stress [8,9]. This aspect of the sustainability-risk interaction is often overlooked. Yet, to the extent that these risks (and costs) emerge, they change the dynamics of sustainability implementation $[10,11]$. Importantly, supply chain risk management is typically regarded as "the ability of a firm to understand and manage its economic, environmental and social risks in the supply chain" [12] (p. 366). From the perspective of the framework shown in Figure 1, sustainability as a risk-mitigation strategy tends to focus on the known-known disruptions that result from socially questionable decisions made in managing product, service, and financial flows. Sustainability-induced risks, by contrast, often emanate from known-unknown and unknown-unknown risks. That is, these are unexpected risks that decision makers have overlooked. As a result, these risks have been poorly articulated and defined [11].

Of course, not all industries are equally vulnerable to sustainability-induced disruptions. To effectively evaluate this more nuanced view of the sustainability-risk interaction, it is important to conduct research in an industry where sustainability and risk interact abundantly and richly [13-15]. The food industry, for instance, is highly susceptible to disruption-especially across production and 
supply chain systems. Indeed, the nature of food operations inevitably intertwines sustainability and risk $[16,17]$.

For example, Chipotle Mexican Grill-the fast-growing, fast-casual restaurant-became an unwilling "poster child" for how sustainability-induced risk can undermine both sustainability and corporate strategies. Specifically, Chipotle developed a large and loyal customer base by serving tasty, affordable food with a food-with-integrity business model. To produce to its sustainability-driven business model, Chipotle sourced products from socially responsible farms and ranches, producing food made with only non-GMO ingredients. However, in 2015, Chipotle suffered several debilitating disruptions, which manifest in two types of risk.

1. Supply Shortage: One of Chipotle's pork suppliers violated animal welfare standards. Unable to acquire sufficient sustainably raised pork, Chipotle was forced to pull carnitas from its menus at 600 restaurants (one third of the retail network).

2. Food Safety: During the summer, more than 500 Chipotle patrons suffered Escherichia coli, norovirus, and salmonella-caused food poisonings. Customers lost confidence and Chipotle's stock price dropped $35 \%$ [18]. No one had previously associated food with integrity-which is often locally sourced and undergoes less handling and treatment-as a likely cause of disease outbreaks.

Sustainability-driven supply shortages and food safety concerns hurt financial performance in two ways. Specifically, they decrease revenues and they increase costs. Thus, decision-makers in food production systems need to recognize that how well they identify and manage sustainability-induced risks will influence the long-term viability of sustainability programs. Understanding the nature of the risks that sustainability introduces into value-added systems can help managers more effectively mitigate risks and the costs they introduce. Such understanding promises to help managers reduce the probability of disruption and the total costs of sustainability programs. Regrettably, research that meaningfully explores sustainability-induced risks remains ad hoc and fragmented $[9,10,16,19]$. Because sustainability-induced risks increase costs and ineffective risk management increases vulnerability, evaluating the sustainability-risk interaction in the food supply chain is both relevant and timely.

To help redress limitations in the extant literature, this research elaborates theory regarding holistic system design to explicitly consider the possibility that sustainability initiatives may introduce risks, and costs, into value-added systems. This research, thus, addresses three research questions:

1. Does sustainability introduce new and unexpected risks into food supply chains?

2. If so, what is the nature of these sustainability-induced risks?

3. How do sustainability and risk interact to influence managerial decision making and ultimately the viability of sustainability programs?

This is done through an inductive, case study research program, focusing on sustainability-induced risks in value-added activities; i.e., production and delivery processes.

This study contributes to the literature by identifying risk factors and consolidating them into core risk categories. Importantly, by detailing key interactions, a dynamic sustainability-risk interaction emerges. The findings reveal that many managers are quite cognizant that their sustainability initiatives are susceptible to supply and food-safety disruptions. However, they routinely ignore these sustainability-induced risks, largely because they do not know how to mitigate these risks and they presume that they will not manifest. A better understanding of the sustainability-risk interaction can help managers proactively mitigate risks from the design stage. Indeed, the findings offer guidance to mitigate risks and facilitate more effective and viable sustainability initiatives.

\section{Theoretical Background: Understanding the Sustainability-Risk Interaction}

\subsection{The Sustainability-Risk Interaction}

The literature on supply chain risks is extensive. Much of the research has focused on identifying risks. For instance, Table 1 lists the risks that have been routinely identified across the extant 
literature e.g., [20-22]. Since they are widely recognized as prevalent risks, analysts often call these known-knowns. Importantly, these identified risks are often categorized based on where they occur. Specifically, many risks like process and business risks take place within the four walls of an organization. Other risks such as worker exploitation at an upstream supplier or a supply shock related to a sourced material are embedded in the supply chain. These risks tend to be harder to identify and mitigate.

Table 1. Types of risks: known-knowns, known-unknowns, and unknown-unknowns.

\begin{tabular}{|c|c|}
\hline \multicolumn{2}{|c|}{ Risk Type } \\
\hline Known-Knowns & $\begin{array}{l}\text { Disruptive events that occur fairly frequently; i.e., } \\
\text { they possess a track record. Data exists to assess } \\
\text { probability they will occur and the severity of their } \\
\text { impact. Commonly discussed in the literature. }\end{array}$ \\
\hline $\begin{array}{ll}\text { - } & \text { Process Breakdowns } \\
\text { - } & \text { Loss of Control } \\
\text { - } & \text { Supply-side Problems } \\
\text { - } & \text { Operational Failures } \\
\text { - } & \text { Macroeconomic Issues } \\
\text { - } & \text { Information-sharing Problems } \\
\text { - } & \text { Market-side Uncertainties }\end{array}$ & $\begin{array}{ll}\text { - } & \text { Financial Failures } \\
\text { - } & \text { Security Issues } \\
\text { - } & \text { Environment-dependent Obstacles } \\
\text { - } & \text { Resource-related Deficiencies } \\
\text { - } & \text { Quality Deficiencies } \\
\text { - } & \text { Technology Breakdowns } \\
& \text { Reputation Loss }\end{array}$ \\
\hline
\end{tabular}

Disruptive events that have happened in the past, but Known-Unknowns without a consistent pattern or history, making assessment speculative. Specific events discussed as case studies in the literature.

- Natural Disasters

- Terrorist Attacks

- $\quad$ Accidents (e.g., fire)

- $\quad$ Product Safety Issues
- $\quad$ Social Issues (e.g., child labor, labor strikes)

- Economic Crisis

- Environmental Issues (e.g., water/energy consumption)

Conceivable but unusual and unexpected events. As rare-even surprising-events, these black swan have a major effect on operations. Literature is less developed; i.e., more ad hoc and fragmented.

- 9/11-magnitude Event

- Dieselgate Emissions Scandal

- Potential fit for sustainability-induced risks.

The extant research has long noted that sustainability and risk are related. In fact, Carter and Rogers [12] (p. 366) explicitly called sustainability "the ability of a firm to understand and manage its economic, environmental and social risks in the supply chain". Unfortunately, this literature is less well developed and more fragmented than the general supply chain risk literature. Even so, research has begun to identify risks that may be induced by sustainability initiatives. Many sustainability-induced risks are likely to fall into the known-known type-occurring both within the firm and across the supply chain. Other sustainability-induced risks-for instance, the norovirus and salmonella outbreaks at Chipotle-might best be classified as known-unknowns [11,23,24]. Managers know these risks exist, but they do not expect to see them often.

Given the nascent nature of the sustainability-risk literature and the nuanced nature of the sustainability-risk relationship, some sustainability-induced risks likely fall in the unknown-unknowns category. These risks may or may not be industry dependent $[13-15,25,26]$. For instance, Volkswagen's Dieselgate scandal is the type of unusual, surprising event that characterizes unknown-unknowns. More research is needed to identify and delineate these risks. 
From a practical standpoint, one question of interest is, "What type of risks does sustainability induce-known-knowns, known-unknowns, or unknown-unknowns?" One point seems clear: adopting sustainability programs changes company's regular business practices, taking companies into a more uncertain and therefore more risky business environment [27]. Thus, research is needed to begin to define the dynamics of the sustainability-risk interaction such that decision-makers can design more-effective, less-risk-sensitive value-added systems.

\subsection{Theoretical Framework: The Dynamics of Sustainability-Risk Interactions}

Several literature streams inform the sustainability-risk interaction e.g., $[8,9,12,16]$. For instance, systems thinking, chaos theory, and theory of constraints (TOC) are identified as central to understanding the process through which sustainability induces risk, potentially undermining sustainability. Each stream's relevance derives from insight provided into the unintended consequences of sustainability system design. Each theory helps elaborate why firms struggle with the process of identifying, evaluating, and mitigating sustainability-induced risks [28]. Although each theoretical perspective yields insight into sustainability system design, none paints a holistic picture of how nuanced risk dynamics hinder a firm's ability to exploit sustainability as a source of competitive advantage.

\subsubsection{Systems Thinking}

Systems thinking posits that by separately optimizing individual activities, the overall system is often sub-optimized $[29,30]$. From a systems perspective, decision-makers should manage supply chains as a cohesive entity, rather than as individual organizations performing independently [31]. Specifically, managers need to recognize and understand how changes at any level in the system affect the overall system [32].

Importantly, adopting sustainability initiatives influences a firm's-and potentially the supply chain's-superordinate goal. For example, to support a "food-with-integrity" mission, Chipotle began to work more intensely with socially responsible suppliers. Over time-and as Chipotle's sales grew-these sourcing decisions created several unanticipated and ultimately disruptive tradeoffs, which manifest in supply constraints. As supply shortages forced Chipotle to remove popular items from the menu, revenues decreased. The choice to be a socially responsible company had increased costs above and beyond what decision makers had originally anticipated. Systems thinking suggests that such unanticipated outcomes are likely to occur when managers fail to fully understand the nature of the system they are managing, especially the elements and their interrelationships. Visibility is the key to evaluating tradeoffs. Naturally, systems that are more complex in terms of both detail and dynamic complexity are less visible, engendering higher risks and unintended outcomes. Sustainability systems, unfortunately, tend to be more complex.

\subsubsection{Chaos Theory}

Chaos theory informs how complexity influences system dynamics. Chaos theory is an evolutionary theory, which views systems as non-linear, complex, and dynamic [33]. Chaos theory describes systems as a set of inter-related parts that interact to achieve a specified outcome. Small changes in an initial element can amplify and impact system performance, as well as how the system grows and evolves. Viewed through the lens of chaos theory, food production system-and supply-chain embedded sustainability programs—are complex adaptive systems, e.g., [34-36]. As such, chaos theory argues that deterministic conditions will produce unpredicted outcomes as sustainability initiatives are implemented [37].

At Chipotle, the "food-with-integrity" mission led to an initial decision; that is, to buy from local, community farms. Since they used fewer chemicals and irradiation, the community farms' production processes were viewed as more environmentally friendly. However, unintended outcomes arose in the form of a series of food safety problems, including Escherichia coli and Norovirus outbreaks. 
Consistent with chaos theory, consequences escalated as customers revolted, revenue plummeted, and investors pummeled Chipotle's stock. Further, as predicted by chaos theory, despite months of investigation, Chipotle never identified the actual source of the food contamination-a result common to complex adaptive systems. Chipotle's sustainability strength had become a serious constraint—and an existential liability [38].

\subsubsection{Theory of Constraints}

The TOC highlights the fact that every system has at least one constraint. More importantly, TOC emphasizes that constraints determine the performance of the entire system. Simply put, the weakest link (i.e., constraint) defines organizational performance [39]. This reality requires that managers should prioritize identifying and mitigating system constraints.

TOC reasons that factors other than manufacturing bottlenecks [40,41] such as people, policies, governmental regulations, supplier capacity, or even mindsets [42,43] can constrain a system, and encourages managers to define anything that limits the performance of a system relative to its goal as a constraint. Viewed through the TOC lens, the underlying causes of supply shortages and food safety concerns are constraints that should be prioritized and carefully managed. In essence, TOC stresses the need to identify, understand, and remove the sustainability-induced risks that constrain supply chain systems.

To summarize, supply chain production and delivery systems-the focal points for most sustainability initiatives-are inherently complex and dynamic systems [44,45]. Sustainability itself introduces diverse tradeoffs that are extremely difficult to assess and manage [2]. The recognition that sustainability initiatives in food production systems may induce risks that negatively impact market and financial performance (see Figure 1) reiterates the need to explore how sustainability and risk intertwine $[9,10,16]$.

\section{Research Methods}

Due to the interaction between risk and sustainability is complex, dynamic, and not well understood, a case-based inductive approach is employed to gain insight into important how and why questions [46]. Phenomenological interviews are especially appropriate for obtaining rich, nuanced insight into questions like, "How have your sustainability initiatives influenced your risk environment?" [47]. The research process included direct participation, observation, and site visits.

\subsection{Sample and Context}

\subsubsection{Country Selection}

Sustainability is not a matter of choice, but a necessity, especially for emerging countries $[48,49]$. By 2025, only one in every seven people will live in developed countries. Further, emerging economies are growing more rapidly than their developed counterparts-two to three times faster than the U.S.-and will soon account for approximately $70 \%$ of world's growth. Emerging countries, with their young populations, growing middle class, fast developing infrastructure, and increasing purchasing power, are becoming key contributors to global economic growth [50]. Yet, most sustainability research focuses on developed economies. This is true despite the fact that operational constraints in emerging markets are quite dynamic, impeding secure sustainable food systems in emerging economies. Moreover, most companies struggle to implement sustainability in emerging economies, calling for more sustainability research in emerging economy settings [49,51].

Acting as a bridge between Europe and Asia, Turkey represents emerging markets well [52,53]. Of note, exports from the Turkish food industry are growing rapidly, and the food industry reached $\$ 100$ billion in 2015. Thus, one key concern for Turkish food production is to integrate social responsibility into everyday operations. For example, in 2015, the market value for the packaged organic food and beverage industry was around $\$ 90$ million USD, which is expected to be $\$ 170$ million by 2020. 


\subsubsection{Industry Selection}

Sustainability and risk management practices vary across industrial sectors e.g., [14,54]. The food production and delivery supply chain is, however, a leader in promoting socially responsible products and practices (from farm to fork) [54]. Of note, sustainability practices and sensitivity to risks vary based on product type $[55,56]$, especially among animal products, which come to market via complex and dynamic supply chains $[14,25,57]$. This study, therefore, focuses on animal products to capture the intricate value-added activities that affect supply scarcity and food safety; the focus is on five animal product supply chains: meat, poultry, dairy, fish, and retail food supply chains.

\subsubsection{Company Selection}

Since the aim is to elaborate a theory regarding how sustainability-induced risks may interact with, and undermine, the initiatives that engendered, companies that employ advanced production and delivery sustainability practices were searched. Such firms and their practices can be considered as extreme cases [58-60]. Using theoretical sampling [58], 26 companies of various sizes and in various channel positions were selected-from product and service supply to manufacturing to retail (see Table 2). Similarly, both local market producers and exporters were included. Since both sustainability and risks occur throughout an organization, decision-makers from various levels of the food production system were interviewed. Finally, because consumers are key members of food supply chains [61], ten additional interviews with consumers were conducted. Contextual information was likewise sought by interviewing a culinary arts academician, and five food markets were observed, as well as attending the monthly meeting of Food Safety Association. In total, 17 contextual data were engaged in collecting events-eleven interviews and six observations-to gain a comprehensive understanding of risks and sustainability practices (see Table 2).

Table 2. Samples of the interviews and observations.

\begin{tabular}{|c|c|c|c|c|}
\hline Supply Chain Position & $\begin{array}{l}\text { Food Product Supply } \\
\text { Chain Types at Which } \\
\text { They Are Considered } \\
\text { as Exemplars }\end{array}$ & $\begin{array}{c}\text { Number of } \\
\text { Employees } \\
\text { (Approximately) }\end{array}$ & $\begin{array}{l}\text { Number of } \\
\text { Interviews } \\
\text { (Observation) }\end{array}$ & Positions of Interviewees \\
\hline \multicolumn{5}{|c|}{ Service Providers } \\
\hline Road Transportation & $\mathrm{DP}, \mathrm{C}$ & 160 & $2(1)$ & $\begin{array}{l}\text { General Manager, } \\
\text { Logistics Manager }\end{array}$ \\
\hline Road Transportation & $\mathrm{DP}, \mathrm{C}$ & 170 & $1(1)$ & General Manager \\
\hline Road Transportation & $\mathrm{RF}$ & $\begin{array}{l}160 \text { Turkey, } \\
5000 \text { Global }\end{array}$ & $1(1)$ & General Manager \\
\hline Maritime Transportation & $\mathrm{F}$ & $+300 \mathrm{GL}$ & 1 & General Manager \\
\hline Air Transportation & $\mathrm{F}$ & 500 & $1(1)$ & Air Cargo Supervisor \\
\hline \multicolumn{5}{|l|}{ Distributor } \\
\hline Distribution Center & M & $\begin{array}{l}55 \text { Aegean Region, } \\
1800 \text { Turkey }\end{array}$ & $1(1)$ & Warehouse Specialist \\
\hline Sales \& Distribution & DP & 68 & $1(1)$ & Sales Manager \\
\hline Sales \& Distribution & $\mathrm{F}$ & 456 & 1 & Sales Manager \\
\hline Dealer & DP & $25-30$ & $1(1)$ & Dealer Manager \\
\hline \multicolumn{5}{|l|}{ Research Center } \\
\hline Food Quality Laboratory & All & 124 & 1 & General Manager \\
\hline Total & 10 & & $11(7)$ & \\
\hline \multicolumn{5}{|c|}{ Material Suppliers } \\
\hline Processing Plant (Farm) & $\mathrm{F}$ & 151 & $1(1)$ & Plant Manager \\
\hline $\begin{array}{l}\text { Processing Plant } \\
\text { (Meat Processing) }\end{array}$ & M & 250 & $1(1)$ & Quality Control Manager \\
\hline Processing Plant (Farm) & DP & $40-45$ & $1(1)$ & Plant Manager \\
\hline Total & 3 & & $3(3)$ & \\
\hline
\end{tabular}


Table 2. Cont.

\begin{tabular}{|c|c|c|c|c|}
\hline Supply Chain Position & $\begin{array}{c}\text { Food Product Supply } \\
\text { Chain Types at Which } \\
\text { They Are Considered } \\
\text { as Exemplars }\end{array}$ & $\begin{array}{c}\text { Number of } \\
\text { Employees } \\
\text { (Approximately) }\end{array}$ & $\begin{array}{l}\text { Number of } \\
\text { Interviews } \\
\text { (Observation) }\end{array}$ & Positions of Interviewees \\
\hline \multicolumn{5}{|c|}{ Finished Goods Producers } \\
\hline Manufacturer & $\mathrm{C}$ & 2000 & $1(1)$ & Quality Control Manager \\
\hline Manufacturer & $\mathrm{D}$ & $110-115$ & $2(1)$ & $\begin{array}{l}\text { Quality Control Manager, Manufacturing } \\
\text { Manager }\end{array}$ \\
\hline Manufacturer & $\mathrm{F}$ & 456 & $1(1)$ & Logistics and Planning Manager \\
\hline Manufacturer & $\mathrm{F}$ & 49 & $1(1)$ & Quality Control Expert \\
\hline Manufacturer & M & $\begin{array}{l}900 \text { Factory, } \\
1800 \text { Turkey }\end{array}$ & $3(1)$ & $\begin{array}{l}\text { Quality Control Manager, Logistics Manager, } \\
\text { Warehouse Manager }\end{array}$ \\
\hline Total & 5 & & $8(5)$ & \\
\hline \multicolumn{5}{|l|}{ Retailers } \\
\hline Retailer & DP, M, C & 2 & $1(1)$ & Grocery Manager \\
\hline Retailer & $\mathrm{DP}, \mathrm{M}, \mathrm{C}$ & 3 & $1(1)$ & Grocery Manager \\
\hline Retailer & DP, M, C & 21000 & $1(1)$ & Supermarket Chain Manager \\
\hline Retailer & F, DP, M, C & 21000 & $1(1)$ & Supermarket Chain Responsible \\
\hline Restaurant & F, DP, M, C & 100 & $1(1)$ & Restaurant Manager \\
\hline Restaurant & RF & 262 , in total & $1(1)$ & Food Country Manager \\
\hline Restaurant & RF & 50, in İzmir Branch & $1(1)$ & Food Branch Manager \\
\hline Restaurant & F, DP, M, C & 38 & 1 & Restaurant Manager \\
\hline Total & 8 & & $8(7)$ & \\
\hline COMPANIES & 26 & & $30(22)$ & \\
\hline \multicolumn{5}{|l|}{ Context } \\
\hline Consumer & All & & 1 & Consumer \\
\hline Consumer & All & & 1 & Consumer \\
\hline Consumer & All & & 1 & Consumer \\
\hline Consumer & All & & 1 & Consumer \\
\hline Consumer & All & & 1 & Consumer \\
\hline Consumer & All & & 1 & Consumer \\
\hline Consumer & All & & 1 & Consumer \\
\hline Consumer & All & & 1 & Consumer \\
\hline Consumer & All & & 1 & Consumer \\
\hline Consumer & All & & 1 & Consumer \\
\hline Academician & All & & 1 & Professor of Culinary Arts and Management \\
\hline Food Safety Association & All & & (1) & Quality Managers \\
\hline Food market & $\mathrm{F}$ & & (1) & Owners and Operators \\
\hline Food market & F & & (1) & Owners and Operators \\
\hline Food market & DP & & (1) & Owners and Operators \\
\hline Food market & RF (incl. F, M, C) & & (1) & Operators \\
\hline Food market & RF (incl. F, M, C) & & (1) & Operators \\
\hline CONTEXT & 17 & & $11(6)$ & \\
\hline MAIN TOTAL & 43 & & $41(28)$ & \\
\hline
\end{tabular}

RF: Retail Food; C: Chicken; M: Meat; DP: Dairy Products; F: Fish.

\subsection{Data Collection}

Semi-structured interviews were conducted face-to-face on site to seek a deeper understanding of how sustainability initiatives have affected operations and introduced new risks into the decision-making environment. Each interview lasted about $60 \mathrm{~min}$. The interview guide consisted of seven open-ended questions designed to probe for risk factors that emerge from environmentally and socially responsible practices. Respondents were asked to describe the company they work for, the structure of their supply chain, and their thoughts on the dynamics of food industry. Later questions explored how sustainability initiatives influenced risks across the firm's operations and supply chain. Respondents were asked to describe how thee sustainability-induced risks differ from more traditional operating risks. The semi-structured interviews enabled the interviewers to probe and explore the interactions among the sustainability-induced risk factors [46]. 
During the interviews, respondents were invited to provide detailed examples that provided thick description, and it is ensured that the respondents' experience was fully reflected [46]. Each interview was recorded, transcribed, and checked for accuracy [59].

Importantly, respondents were asked to discuss each food type sequentially; that is, one at a time. If the key informant began to speak in general non-specific terms, the interviewer guided the discussion back to the specific food product type under consideration. Further, to avoid social desirability bias, decision-makers from different levels of each food production system were interviewed, seeking as much diversity and triangulation as possible [46]. Interview data was enriched and grounded by observations at 28 sites. Employees were engaged in many informal discussions at the factories and warehouses in order to match interview comments to real experiences.

\subsection{Data Analysis}

The qualitative data were analyzed by an iterative process of building, testing, and revising categories, and travelling back and forth between the data and the emerging themes [62,63]. First, the open codes were identified [62]; then, these were used to outline first-order codes. A further consolidation was made among these categories, which moved the data towards a more theoretical axial coding scheme. Categories with emerging data was constantly compared as the interview process was progressed [62,64]. Two main steps were employed.

Step 1: Identifying latent meanings and creating first order codes. Since the interviews were conducted across industries and supply chains, different words were often used to convey the same meaning. Likewise, similar words were often used to convey different meanings. Therefore, the latent meanings of the words and concepts were interpreted in content analysis to better identify and delineate associated risk factors.

Step 2: Integrating theoretical codes and creating categories. As Figure 2 shows, individual supply chain risk factors were consolidated and re-labeled based on inherent similarities [62]. The three academicians who established the original theoretical codes validated these consolidated theoretical categories [47].

Panel A: Behavioral

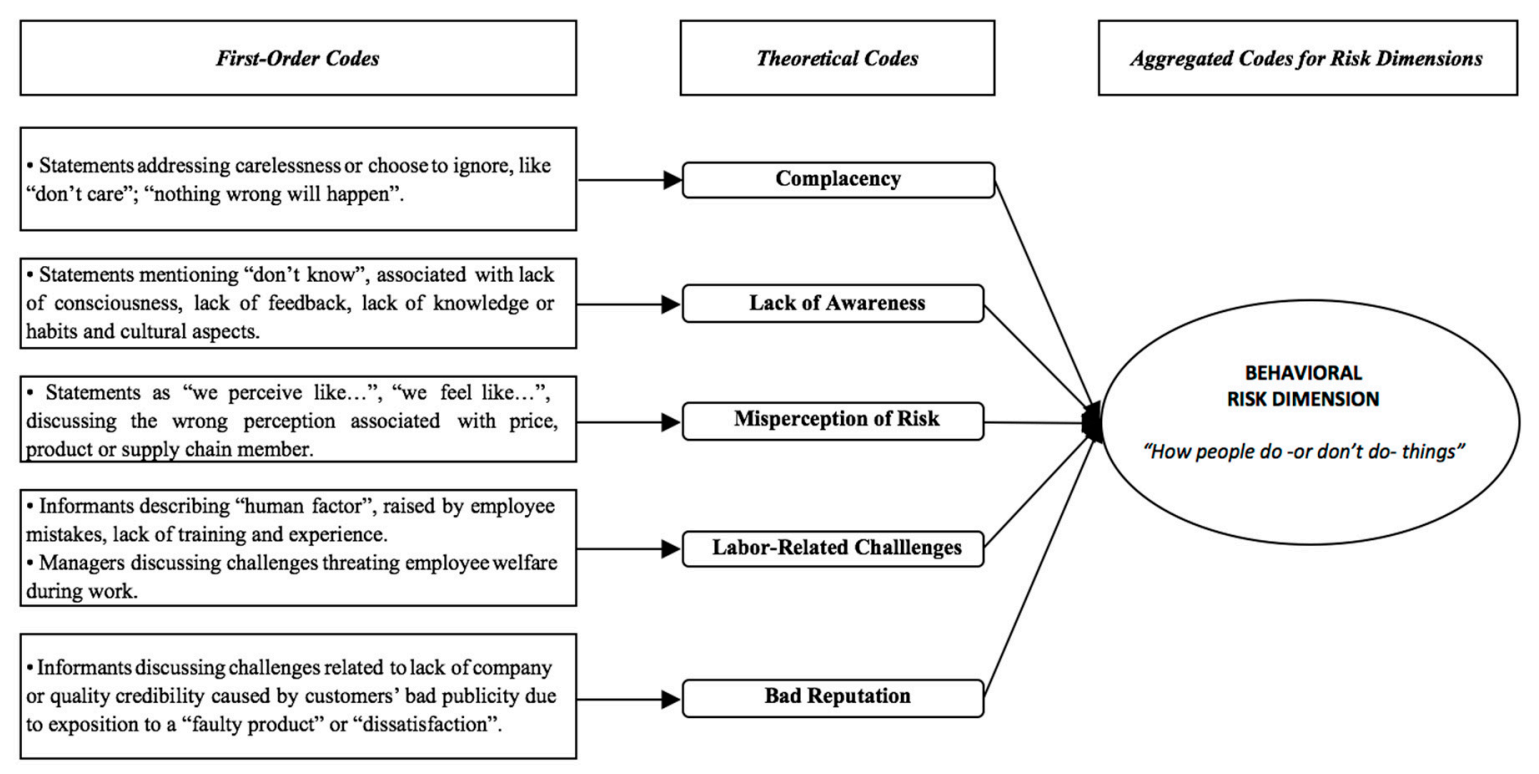

Figure 2. Cont. 


\section{Panel B: Opportunism}

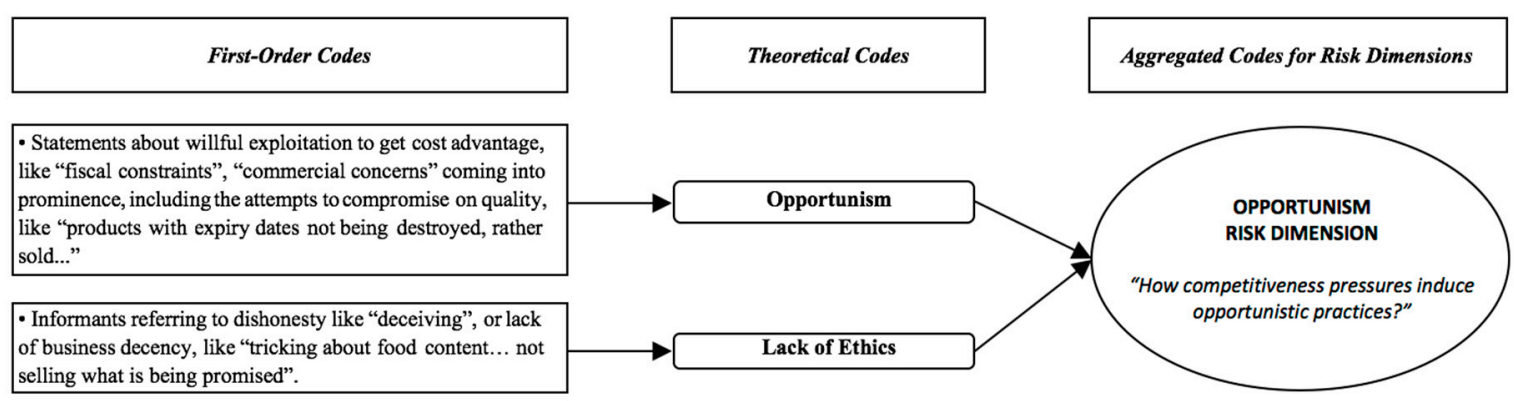

\section{Panel C: Organizational Routines}

\begin{tabular}{|l|l|}
\hline First-Order Codes & Theoretical Codes \\
\hline
\end{tabular}
- Managers stating challenges to control supply chain
members "....sector where partner controlling is poor...".
- Statements addressing difficulties to secure processes “...
the weakest, the most uncontrollable point...".

- Informants describing weakness due to poor corporate policies and practices ("don't have procedures... have not carried out an appropriate practice..." or insufficient systematic management "to avoid risks...a proper procurement policy is required right from the start...".

- Statements referring to lack of compliance issues and process legality ("black market entities in food industry...", "non-invoiced sales", or insufficient regulative framework like "...there is a certain standard... but no regulation that explains this...".

- Managers claiming about lack integral span of control ("...have tracking system, but not integrated to the entire chain...") and lack of integrated perspective "all individual parts not treated as a chain..."

- Statements about inaccurate or incorrect inventory planning mainly due to "demand forecasting" resulting in "shelf life expired products".

- Managers discussing problems about capacity-related issues like "storage capacity", "production capacity"

- Managers discussing about deficiencies in ordering process due to "wrong kg delivery" or "not being able to meet the orders caused by livestock-related processes..."

- Statements related to "no change", being common in the industry. This is associated with non-intention to adopt environmental advancements, especially related to "not taking enough advantage of technology", or make proces improvements like "follow the world and change to survive" or "poor complaint management hindering change".

- Informants discussions about insufficient focus on labor development like "... not investing on labor to take licences or certificates"

- Managers addressing "lack of proactive approach to risk management".

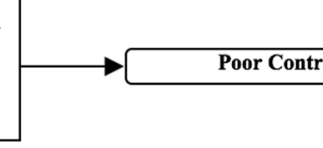

at
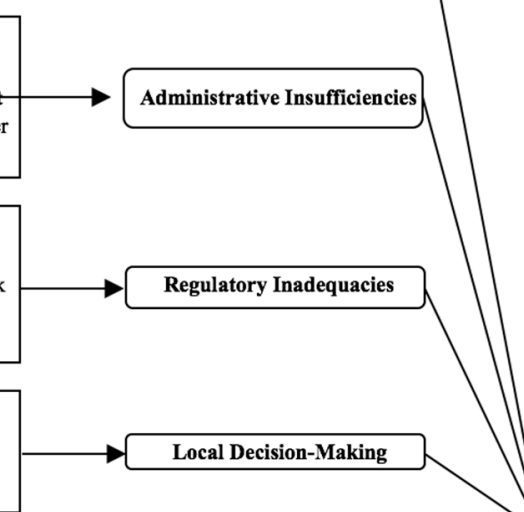

- Statements about unforeseen contamination or unaccountable poisoning threats related to "lack of hygiene", "physical substances", "microbiological or chemical hazards", "bacterial growth".

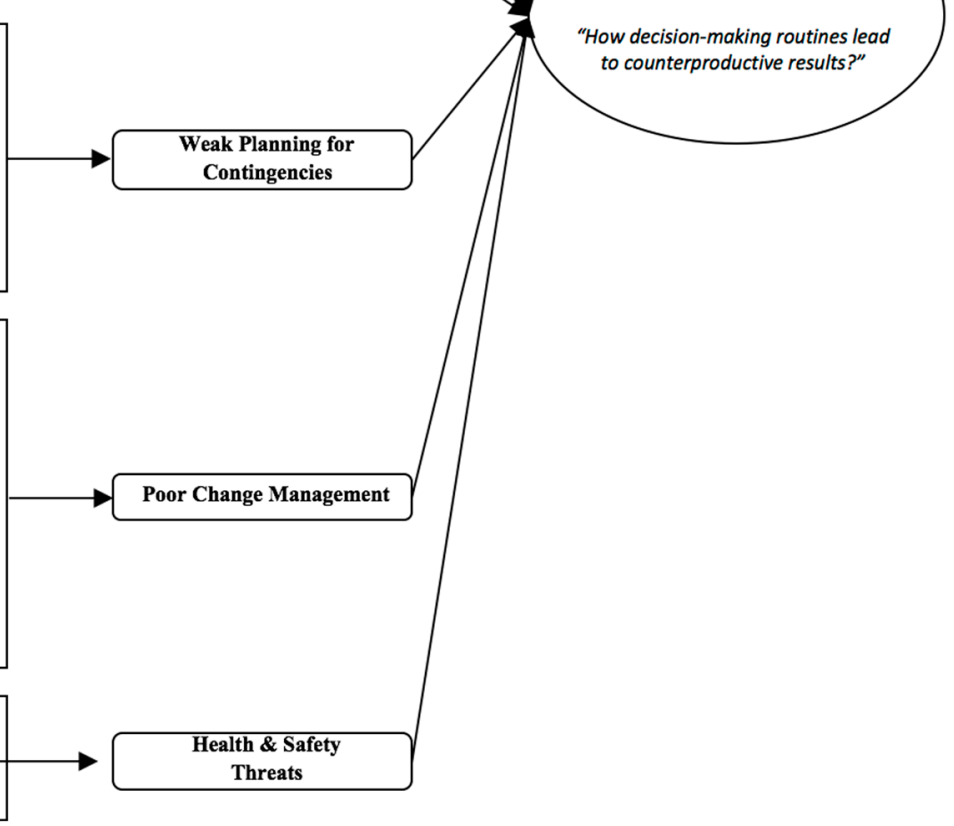

Figure 2. Cont. 
Panel D: Safety and Traceability Routines

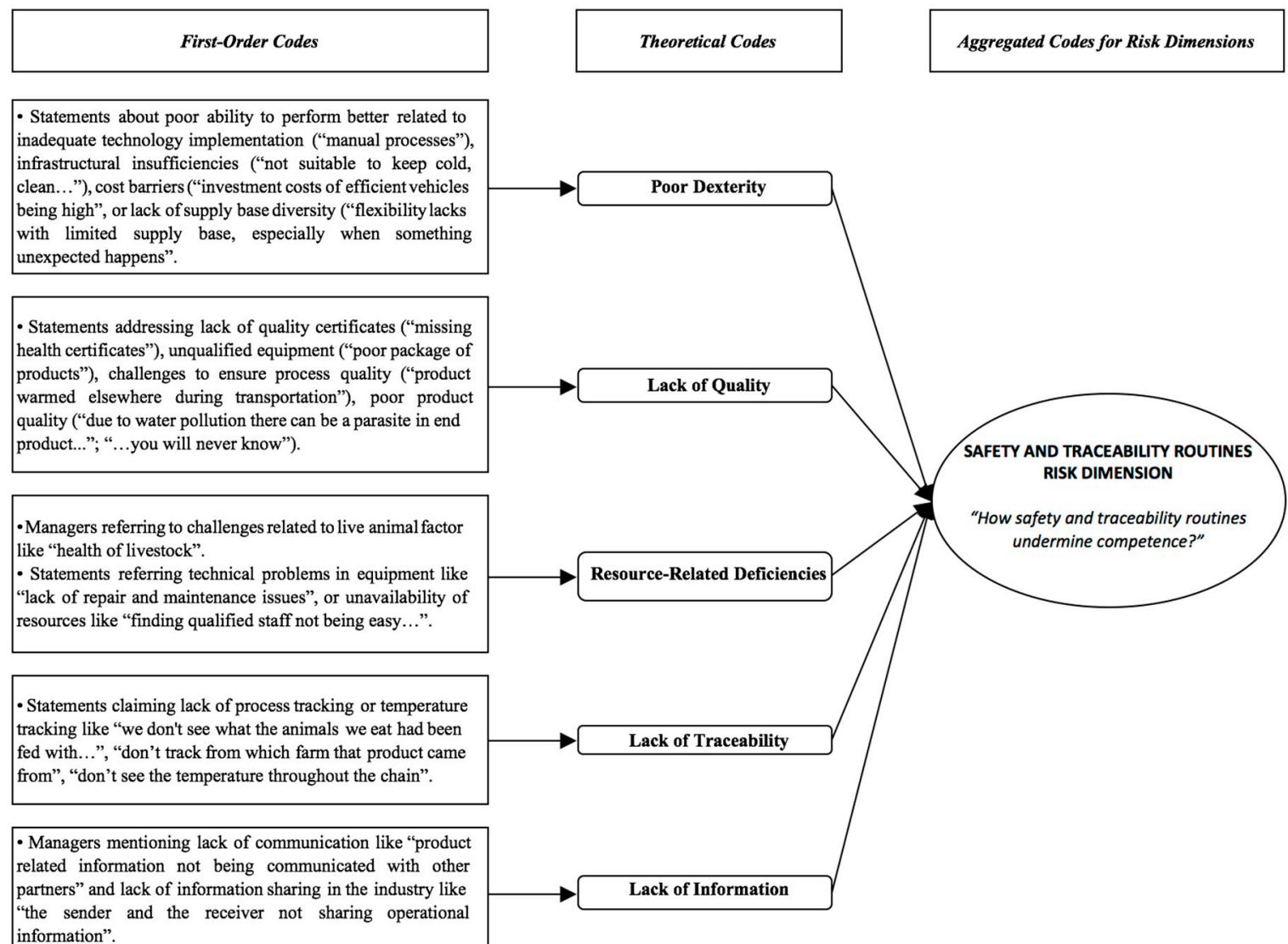

information".

\section{Panel E: Systems Design}

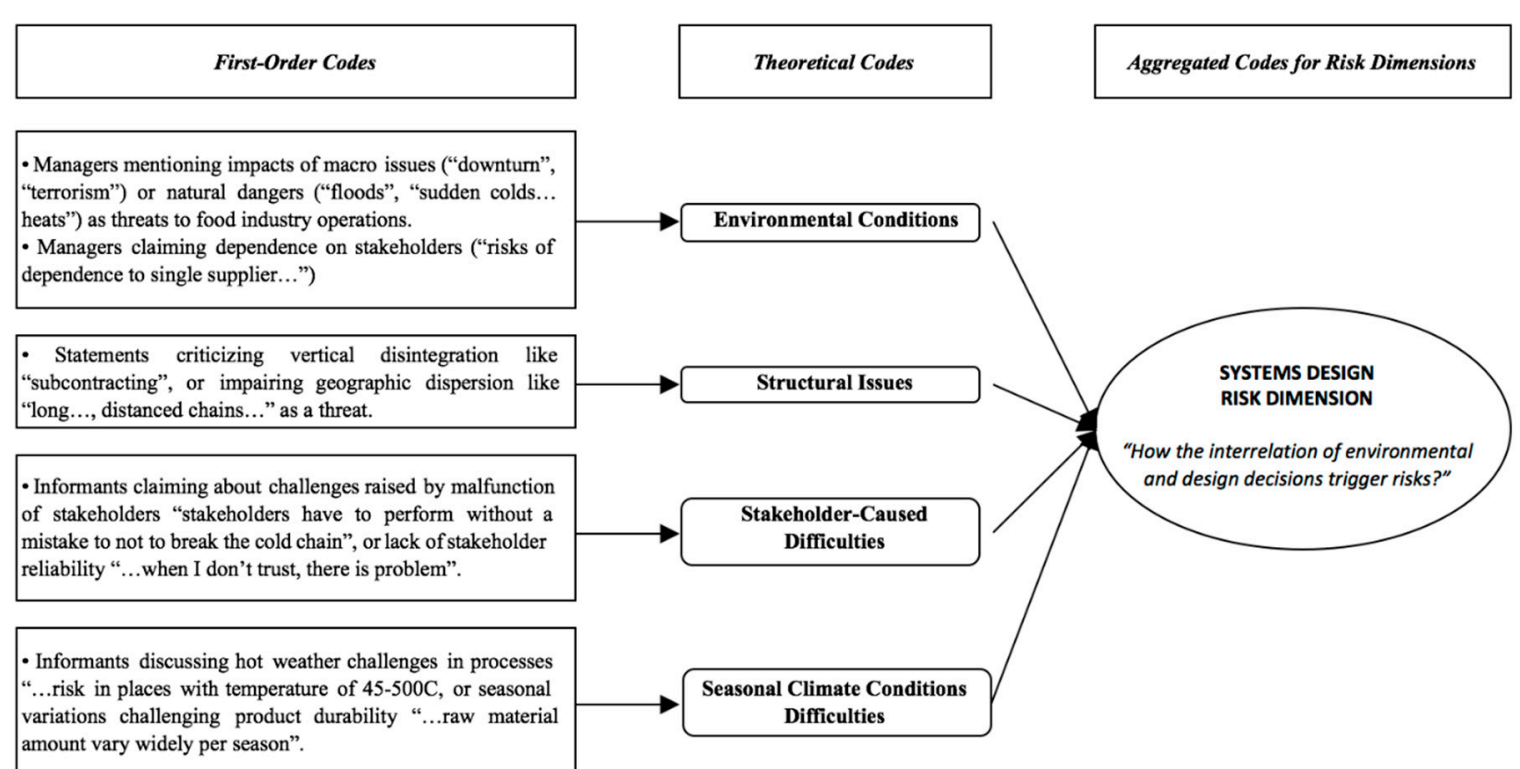

Figure 2. Sustainability-induced risks in food supply chains: overview of the data structure.

\subsection{Reliability and Validity of the Research}

To assess validity, reduce interpretive bias, and increase the reliability of findings, the procedures recommended by Yin [46] (see Table 3) were employed. In this study, three sustainability researchers 
coded and interpreted the interview and observational data in an iterative fashion, discussing discrepancies until a consensus of meaning was obtained [47]. Inter-subjectivity of data analysis was reported through discursive alignment of interpretation, a method commonly used in latent content analysis, e.g., $[16,65,66]$.

Table 3. Reliability and validity of the research.

\begin{tabular}{|c|c|}
\hline Test & Implementation in Food Supply Chain Case Study and Content Analysis \\
\hline Internal Validity & $\begin{array}{l}\text { Multiple food product types are selected } \\
\text { Cases included semi-structured interviews and observations } \\
\text { Different relationships are examined among different levels of supply chain members } \\
\text { Discussed and documented interviews. }\end{array}$ \\
\hline Construct Validity & $\begin{array}{l}\text { Multiple sources of evidence are explored in multiple food product type studies, a } \\
\text { chain of evidence is established and the case report is discussed by three key } \\
\text { respondents } \\
\text { Used informants with different perspectives and conflicting interests which are also } \\
\text { from different organizational levels belonging different food product chain types } \\
\text { Two key informants reviewed the case report } \\
\text { Multiple documents are collected and reviewed } \\
\text { A great attention is given on the sampling design and analysis. }\end{array}$ \\
\hline External Validity & $\begin{array}{l}\text { Multiple food product types are studied } \\
\text { Used and followed a case study protocol throughout the case study } \\
\text { Created a case study database. }\end{array}$ \\
\hline Reliability & $\begin{array}{l}\text { All interviews are recorded in good-quality, transcribed into text format in details } \\
\text { Case study protocol is used to document the procedures followed, and the complete } \\
\text { operational process and case study database is formed } \\
\text { Multiple coders analyzed transcript data to check whether the codes and themes are } \\
\text { coded the same way as in the analysis } \\
\text { The coding and interpretation process is checked by three academicians on the field } \\
\text { and the extent to which they have arrived at the same findings is reported } \\
\text { Reproductivity is reported through discursive alignment of interpretation. }\end{array}$ \\
\hline
\end{tabular}

\section{Findings and Discussion}

Examining the data thoroughly, three main findings were arrived at regarding sustainability-induced risks and their interaction in food production systems; each addressing to the three research questions: (1) sustainability induces known-known, known-unknown, and unknown-unknown risks, increasing costs across the food production and supply chain systems; (2) deeply ingrained thought processes and behaviors permeate each of the risk dimensions; and (3) diverse and distinct risks comingle to create a high level of detail complexity, often overwhelming attempts to mitigate risk.

\subsection{The Nuanced Nature of Sustainability-Induced Risks}

Sustainability goals introduce a layer of complexity across the food supply chain, exacerbating the challenge of bringing safe and affordable food to the market. Specifically, the desire to pursue socially responsible practices induces process complexity and supply constraints, which magnify risks across almost all value-added activities. Indeed, 61 distinct risk sub-components were identified, which were distilled into 23 core risk factors and five risk dimensions (Appendix A), which are discussed below.

\subsubsection{Behavioral Risks}

Behavioral risks emerge from what decision-makers do-or do not do-as they interact with the food production system. That is, they focus on day-to-day operating behaviors. As Table 4 illustrates, the interviews revealed that counterproductive behaviors lead to unintended consequences at almost every touch point. Yet, managers frequently underestimate behavioral risks, a reality triggered by 
culture, experience, and a lack of awareness of the impact of specific behaviors. As a result, bad habits persist across the food production system, often because many people who touch the system are resigned to a perception that they cannot do anything about the risks. Fatalism undermines the change initiatives required to operate sustainably at low risk levels. The defeatist mindset perpetuates inaccurate perceptions of the way work should be done, embedding counterproductive behaviors more deeply.

Table 4. Quotes for behavioral risk dimension.

\begin{tabular}{|c|c|c|}
\hline Risk Factor & Power Quote & Proof Quote \\
\hline $\begin{array}{l}\text { Complacency: Any risk factor } \\
\text { related to passivity or } \\
\text { complacency of individuals. }\end{array}$ & $\begin{array}{l}\text { "Distributors drop off goods on the streets ... } \\
\text { at } 50 \text { degrees. The product is delivered to the } \\
\text { store without air conditioning. The product is } \\
\text { put in the refrigerator again. Then the customer } \\
\text { buys it and puts it into bags at } 45 \text { degrees ... } \\
\text { and carries it around for 3-4 h. S/he goes home } \\
\text { and puts it in refrigerator again. These are the } \\
\text { conditions in Turkey. We, as Turkish people, } \\
\text { think like 'nothing bad will happen'". "Product } \\
\text { is spoilt because our people just don't care } \\
\text { enough". }\end{array}$ & $\begin{array}{l}\text { "Nothing bad will happen. We feel } \\
\text { like it doesn't matter". "Anything } \\
\text { can happen! But they don't care". }\end{array}$ \\
\hline
\end{tabular}

"First, we need to be aware as consumers ... because... we are both producers and consumers. You are going to the factory .... as the manager, the producer. Then you go home at night; buy products from the supermarket as a consumer. First, we need to be a conscious society". "There are studies on sustainability ... but the education level is quite low. [It's] all about insufficient awareness; since we don't understand and know about hazardous consequences, we don't contribute". "In Turkey, we want to get every job done fast. This is our culture. And this is how managers decide and what they measure. They don't know or care about the rest! Anything can happen!"

"Red gills in a fish is perceived as freshness. But the story is different. If that fish waits in water for a day, the blood in the gills passes into the water. There you have white gills. When we sell it, this becomes a huge problem. Your customer conducts quality control, sees the white gills ... no matter how good the meat quality is ... they perceive it as dated. You cannot sell that fish because of this false perception".

"The human factor is very important surely. If you consider companies, they make incredible investments in quality and laboratories. But when you consider drivers, you know, we are all human. However, it is the driver who completes the entire chain, not the company itself". "When the human factor is involved, it makes things more difficult. People all make mistakes; minimizing this is crucial".

"Loss of customer confidence will generate a bad reputation for them. Not only will they

Bad Reputation: Any risk factor related to failing to build a true image or confidence in the opinion of stakeholders. lose reputation in the eyes of the customers, but it will also be bad publicity compared to their competitors, and thus they will face such an integrated and sophisticated effect. They may even lose the market; in the most extreme situation, they may go bankrupt".
"Too many unaware people work in the food sector."

"The consumer is not aware, doesn't know anything."

"[Consumers] perceive the natural one is the local one sold by villagers". "They perceive it as expensive. It is NOT; it costs what it's worth".

"You can design everything perfect ... but humans ... cannot be perfect". "A flaw may arise due to personnel".
"If you provide a faulty product that affects your image in the eyes of the customer". "You can dissatisfy people once; there is NO second time". 
Critically, managers frequently described a "don't care" attitude among food industry employees. The attitude emerges from two core perceptions. First, employees believe that "nothing bad will happen" from current behaviors, a perception that is particularly perilous in cold-chain channels. Second, managers perceive that customers really do not care about social responsibility-at least not enough to be willing to pay extra for state-of-the-art sustainability or risk-mitigation practices. Interestingly, interview managers noted that although consumers do not take sustainability arguments/evidence seriously, they are quick to share bad publicity.

Ultimately, a lack of societal awareness and sustainability education at all levels-from raw materials producers to end consumers-undermine the motivation to engage deeply in social responsibility and risk mitigation. Although deep awareness and a willingness to pay more for sustainable products is problematic in developed markets [2], the problem is greatly magnified in emerging economies. Decision-makers in emerging economies value different things than their developed-economy counterparts. In other words, although sustainability and risk mitigation are hot topics in the affluent world, decision-makers perceive that citizens of emerging markets cannot afford to pay for the luxury of sustainability and risk mitigation. In emerging economies, a large portion of the population struggles to eke out a comfortable lifestyle. They are not highly concerned about the degree of risk or sustainability in the food production system. The result: managers and workers alike focus on minimizing short-term, local costs and perceive no compelling reason to alter behaviors, especially when changed behaviors increase costs and threaten competitiveness.

Indeed, the interviews highlight that behavioral risks persist everywhere affecting (often magnifying) other risks. Managers prominently and pervasively discussed that behavioral issues, like lack of awareness, ignorance or carelessness, stimulate other risk categories, and threaten to sub-optimize the performance of both the food production system and key sustainability initiatives. This makes behavioral risks a superordinate risk category and merit the most; and most immediate, remediation efforts in behavioral risks provide a multi-faceted return. Risk mitigation efforts should thus importantly target behavioral risks. Yet, despite being a very prominent and pervasive risk, behavioral risks are not just overlooked but are widely accepted as inevitable.

\subsubsection{Opportunism Risks}

Interview managers repeatedly related that competitive pressures induce exploitive practices and "corner cutting" across the food production and delivery supply chain. Thus, a separate category of risks was created. Specifically, behavioral risks focus on day-to-day operating behaviors. By contrast, opportunism risks focus on ethical practices. As the quotes in Table 5 illustrates, opportunism manifests as excessive self-interest that violates ethical rules and moral conduct. Managers specifically noted breaches in honesty, fairness, integrity, equity, and legitimacy. In extreme instances, blatant pursuit of self-interest leads to ethical violations and non-compliance with rules for the public welfare $[13,67]$.

Beyond competitive pressures and the quest for economic success, corner cutting emerges from culturally embedded behaviors (see previous discussion). Such behavior is particularly prevalent in settings where decision-makers are rewarded for "saving the day" rather than focusing on long-term social responsibility and risk mitigation. The result: food quality is compromised and supply constraints are overlooked. Indeed, exploited suppliers seldom go the extra mile to help abusive customers achieve sustainability goals or mitigate risk. The intense cost pressure that motivates opportunism impedes investments in risk mitigation. So, corner cutting and non-compliance persist. 
Table 5. Quotes for opportunism risk dimension.

\begin{tabular}{|c|c|c|}
\hline Risk Factor & Power Quote & Proof Quote \\
\hline $\begin{array}{l}\text { Opportunism: Any risk factor } \\
\text { arising from supply chain partners' } \\
\text { self-interested efforts to exploit. }\end{array}$ & $\begin{array}{l}\text { "He doesn't switch on the cooler to save the } \\
\text { costs of consuming oil fuel". "Unfortunately, } \\
\text { food safety is usually ignored since economic } \\
\text { factors predominate". }\end{array}$ & $\begin{array}{l}\text { "For commercial greed, even big } \\
\text { brands administer antibiotics, } \\
3 \text { days after they slaughter the } \\
\text { chickens". "Opportunism is } \\
\text { everywhere in this sector". }\end{array}$ \\
\hline $\begin{array}{l}\text { Lack of Ethics: Any risk factor } \\
\text { caused by violation of ethics or } \\
\text { compliance. }\end{array}$ & $\begin{array}{l}\text { "Some run the following scam: they cover } \\
\text { eggs with hay and sell them as village eggs. } \\
\text { However, maybe they were produced by the } \\
\text { most antibiotics-vaccinated hen". "The } \\
\text { biggest risk is tricks in the production: the } \\
\text { use of pork meat instead of beef... even the } \\
\text { producer begins deceiving you". "It is related } \\
\text { to ethics. If it is chicken sausage, it needs to } \\
\text { be hundred percent chicken. Implementing } \\
\text { what you have promised is ethical". }\end{array}$ & $\begin{array}{l}\text { "The greed of people". "These } \\
\text { frauds start from production". } \\
\text { "They said this minced meat is } \\
\text { spoiled, that it smells. He was } \\
\text { already a cunning man, put it in } \\
\text { deliberately". }\end{array}$ \\
\hline
\end{tabular}

\subsubsection{Organizational Routines Risks}

Looking beyond the actual food production system, managers complained that broader organizational routines support neither sustainability nor risk mitigation (see Table 6). Efforts to pursue more socially responsible production places greater strain on already-stressed routines. Too often, bureaucracy drives administrative inefficiency, undermining regulatory compliance. Further, an emphasis on local decision-making hinders planning processes and day-to-day management of health and safety systems. Moreover, managers reiterated that their organizations just are not very good at managing change. In fact, poor complaint management means that companies often remain unaware of when and where socially responsible practices are being hindered or breaking down. The bottom line: Existing organizational routines make it hard to define procedures, comply with regulations, and develop control and/or coordination across organizational boundaries.

Table 6. Quotes for organizational routines risk dimension.

\begin{tabular}{|c|c|c|}
\hline Risk Factor & Power Quotes & Proof Quotes \\
\hline $\begin{array}{l}\text { Poor Control: Any risk factor } \\
\text { related to lack of detection of } \\
\text { important errors }\end{array}$ & $\begin{array}{l}\text { "Big supermarkets are audited ... but small } \\
\text { supermarkets, groceries, open markets are } \\
\text { not. However, the big threat comes from } \\
\text { small-scale ones ... because big brands } \\
\text { manage their risks to protect brand value". "I } \\
\text { don't control sub-suppliers. It should be done } \\
\text { but it is obviously a big thing. I've never } \\
\text { heard of anyone doing it. This is something } \\
\text { complicated". }\end{array}$ & $\begin{array}{l}\text { "No audits related to cold chain". } \\
\text { "It is a sector where partner } \\
\text { monitoring is poor". "It becomes } \\
\text { less well-monitored when it gets } \\
\text { closer to the end user". }\end{array}$ \\
\hline $\begin{array}{l}\text { Administrative Insufficiencies: } \\
\text { Any risk factor caused by failures } \\
\text { in developing the procedures for } \\
\text { performing activities and } \\
\text { arrangements to run a business }\end{array}$ & $\begin{array}{l}\text { "Of course, risks do exist ... but when you } \\
\text { establish rules from the beginning and } \\
\text { implement them strictly and properly, this is } \\
\text { reflected in our own personnel. When they } \\
\text { see this attention in terms of management and } \\
\text { the organization, it is reflected in the practices } \\
\text { of the producer, and the seller". "Food safety } \\
\text { is something that can be managed. What is } \\
\text { important here is to accurately build and } \\
\text { follow procedures, predict risks and prevent } \\
\text { them. Struggling with risks, avoiding risks, } \\
\text { requires a proactive approach, not reactive". }\end{array}$ & $\begin{array}{l}\text { "Social responsibility procedures } \\
\text { are very deficient". "If you don't } \\
\text { have procedures, you will not be } \\
\text { able to manage numerous } \\
\text { products". }\end{array}$ \\
\hline
\end{tabular}


Table 6. Cont.

\begin{tabular}{|c|c|c|}
\hline Risk Factor & Power Quotes & Proof Quotes \\
\hline $\begin{array}{l}\text { Regulatory Inadequacies: Any risk } \\
\text { factor related to the lack or } \\
\text { non-enforcement of regulations }\end{array}$ & $\begin{array}{l}\text { "There are many black-market entities in } \\
\text { the market. It leads to unfair competition". } \\
\text { "I am confident that companies will } \\
\text { approach it differently if legal sanctions are } \\
\text { implemented strictly." }\end{array}$ & $\begin{array}{l}\text { "The food market should better be } \\
\text { regulated". "The problem is } \\
\text { non-invoiced sales. Turkey is still } \\
\text { behind in such commercial } \\
\text { matters". }\end{array}$ \\
\hline $\begin{array}{l}\text { Local Decision-Making: Any risk } \\
\text { factor caused by the lack of a } \\
\text { holistic perspective in supply } \\
\text { chains }\end{array}$ & $\begin{array}{l}\text { "There should be a risk management } \\
\text { department in individual members. They } \\
\text { should cooperate with each other... but } \\
\text { companies don't perceive it as supply } \\
\text { chain". "Companies need to know the } \\
\text { stages before and after themselves, and if } \\
\text { they do not look at the entire chain } \\
\text { holistically, there is no sustainability in their } \\
\text { supply chains". }\end{array}$ & $\begin{array}{l}\text { "We have tracking system but it is } \\
\text { not integrated into the entire } \\
\text { chain". "It starts from the fish feed } \\
\text { and continues up to the customer. } \\
\text { I should not exclude anything". }\end{array}$ \\
\hline $\begin{array}{l}\text { Weak Contingency Planning: Any } \\
\text { risk factor caused by the inability } \\
\text { to plan for the unexpected }\end{array}$ & $\begin{array}{l}\text { "Milk is not an item that can be stocked. We } \\
\text { should produce milk today then dispatch it } \\
\text { within } 24 \text { hours. You have no chance to sell } \\
\text { it after that". "We have capacity problems } \\
\text { in overseas air transportation. We met with } \\
\text { an airline. They can't say it can be fixed in } \\
\text { the short term". }\end{array}$ & $\begin{array}{l}\text { "One of risks is poor planning". } \\
\text { "Demand forecasting is crucial. } \\
\text { The more mistakes on your } \\
\text { forecast, the more the food may be } \\
\text { spoiled". }\end{array}$ \\
\hline $\begin{array}{l}\text { Poor Change Management: Any } \\
\text { risk factor related to the inability } \\
\text { and resistance to change }\end{array}$ & $\begin{array}{l}\text { "If you can't receive a customer complaint, } \\
\text { this is a risk for us because if that complaint } \\
\text { can't ever reach me, I can't take any } \\
\text { precautions to prevent this. Maybe I've } \\
\text { been making a mistake in my process that I } \\
\text { couldn't see before, because risk is at any } \\
\text { point". "It is critically important to change. } \\
\text { We do implement changes ... but this is not } \\
\text { common in the industry". }\end{array}$ & $\begin{array}{l}\text { "If you improve, you eliminate } \\
\text { risk in any business". "You should } \\
\text { not keep up with contemporary } \\
\text { technology; you should follow the } \\
\text { world". }\end{array}$ \\
\hline $\begin{array}{l}\text { Health \& Safety Threats: Any risk } \\
\text { factor threatening the health and } \\
\text { safety of any individual }\end{array}$ & $\begin{array}{l}\text { "What we call hygiene is the prevention of } \\
\text { biological infections, such as personal } \\
\text { hygiene, environmental hygiene. The cold } \\
\text { chain alone is not enough; hygiene plus } \\
\text { cooling is a must". "If someone with any } \\
\text { disease is working in production, when that } \\
\text { person contaminates the food, millions of } \\
\text { microbes can infect millions of people and it } \\
\text { might pose a serious risk". }\end{array}$ & $\begin{array}{l}\text { "There are physical substance } \\
\text { dangers". "The risk of illness in } \\
\text { animals is very important as it can } \\
\text { contaminate the food". }\end{array}$ \\
\hline
\end{tabular}

One frustrating challenge is the lack of an adequate auditing process across the food industry, especially among smaller operators. Underdeveloped regulatory frameworks impede implementation of sustainability and food safety programs. Black-market entities arise and non-invoiced sales occur, creating unfair competition and promoting corner cutting. These organizational issues challenge most industries. However, the sensitivity of the products in food production system make such failures especially debilitating as they allow foodborne health and safety threats to remain unmitigated.

\subsubsection{Safety and Traceability Routines Risks}

Managers frequently described how poorly designed safety and traceability routines undermine food safety and supply assurance (see Table 7). Food safety was a greater concern than shortages of responsibly-sourced supply. Despite the expressed concerns, managers pointed out that firms do not proactively invest in safety and traceability routines to support higher levels of sustainability. The return on investment for such investments is often too low to justify the efforts. Yet, if safety and traceability routines are not modernized, they can threaten not just sustainability, but also the entire business model. Managers identified traceability and control and a lack of qualified and capable employees as limits on effective safety and traceability routines. 
Table 7. Quotes for safety and traceability routines risk dimension.

\begin{tabular}{|c|c|c|}
\hline Risk Factor & Power Quote & Proof Quote \\
\hline $\begin{array}{l}\text { Poor Dexterity: Any risk factor } \\
\text { that prevents a supply chain from } \\
\text { performing an action skillfully, } \\
\text { quickly and effectively. }\end{array}$ & $\begin{array}{l}\text { "It is not only the food; the biggest } \\
\text { threat is the flexibility of the } \\
\text { supply chain. We have seen } \\
\text { during the crises that even the best } \\
\text { supply chains may collapse ... } \\
\text { because they think that they built } \\
\text { them up perfectly. However, when } \\
\text { something unexpected happens, } \\
\text { they cannot respond with the } \\
\text { same flexibility". }\end{array}$ & $\begin{array}{l}\text { "It is not easy to detect what } \\
\text { happens in transit if you don't } \\
\text { have an online monitoring } \\
\text { system". "We issue waybills } \\
\text { manually. This reduces } \\
\text { productivity and is open to } \\
\text { errors". }\end{array}$ \\
\hline $\begin{array}{l}\text { Lack of Quality: Any risk factor } \\
\text { related to the failure to meet } \\
\text { expectations regarding a product } \\
\text { or service. }\end{array}$ & $\begin{array}{l}\text { "The quality of the raw material is } \\
\text { the priority. You cannot make a } \\
\text { quality product from poor quality } \\
\text { raw materials". "Antibiotics and } \\
\text { hormones given to Animals } \\
\text { damages food quality". }\end{array}$ & $\begin{array}{l}\text { "Carriers don't have quality } \\
\text { certificates". "The delivery process } \\
\text { cannot guarantee protecting the } \\
\text { quality of products". }\end{array}$ \\
\hline $\begin{array}{l}\text { Resource-related Deficiencies: Any } \\
\text { risk factor related to } \\
\text { non-functionality, uncertainty, } \\
\text { failure or lack of resources. }\end{array}$ & $\begin{array}{l}\text { "If you have your own fish, you } \\
\text { take a livestock risk. It is one of } \\
\text { our biggest risks at sea". "Not } \\
\text { supplying the raw material is the } \\
\text { biggest obstacle for that chain. In } \\
\text { the food sector, companies have } \\
\text { supply difficulties; that's actually } \\
\text { a risk". }\end{array}$ & $\begin{array}{l}\text { "You need to have a good vet, } \\
\text { good equipment and a clean place } \\
\text { to avoid risks". "To find qualified } \\
\text { staff is not easy in this sector". }\end{array}$ \\
\hline $\begin{array}{l}\text { Lack of Traceability: Any risk } \\
\text { factor caused by problems in } \\
\text { following, tracking and tracing the } \\
\text { logistics activities of a product, an } \\
\text { activity or a process, without clear } \\
\text { information. }\end{array}$ & $\begin{array}{l}\text { "We have to trace the processes. } \\
\text { Even the traceability of a sheep } \\
\text { gut casing is important. When } \\
\text { there is bacterial load, e.g., in } \\
\text { sausage, it needs to be pulled from } \\
\text { the market: which sheepskins } \\
\text { were used on the sausages, which } \\
\text { companies supplied them, and } \\
\text { which companies were they } \\
\text { distributed to? We need to know } \\
\text { which sausages to pull from the } \\
\text { shelves. It would be a huge loss } \\
\text { for us to pull the entire production. } \\
\text { Traceability is critical, especially in } \\
\text { food companies". }\end{array}$ & $\begin{array}{l}\text { "We don't know what we eat; we } \\
\text { can't track what the animals we } \\
\text { eat were fed on". "The biggest risk } \\
\text { is heat values of products, and we } \\
\text { have to track them". }\end{array}$ \\
\hline $\begin{array}{l}\text { Lack of Information: Any risk } \\
\text { factor preventing the } \\
\text { dissemination of complete, } \\
\text { readily-available, consistent, } \\
\text { visible, accurate and secure } \\
\text { information. }\end{array}$ & $\begin{array}{l}\text { "The consumer must absolutely be } \\
\text { informed as part of social } \\
\text { responsibility to avoid potential } \\
\text { hazards. We see public service ads, } \\
\text { e.g., 'Don't smoke', but don't see } \\
\text { ads like 'Don't put food back in } \\
\text { the fridge once it is dissolved". } \\
\text { "We have to know the exact details } \\
\text { of the product in the customs } \\
\text { office. I mean the customer side } \\
\text { and our side have to be very well } \\
\text { integrated to not break the cold } \\
\text { chain. Lack of information sharing } \\
\text { is this risk". }\end{array}$ & $\begin{array}{l}\text { "Customer-manufacturer } \\
\text { communication is critical to avoid } \\
\text { spoilage". "There is no expiry date } \\
\text { information on the product } \\
\text { package after opening. However, } \\
\text { this is important". }\end{array}$ \\
\hline
\end{tabular}


More specifically, limited traceability is a pain point across Turkish food production and delivery systems. Companies are unable to track the origin of food products, making it more difficult to assure products are sourced from socially responsible suppliers. Further, when food contamination occurs, it is more difficult to identify the root cause. If companies cannot identify which batch of product to recall, they have to expand the recall, greatly increasing their costs. Similarly, temperature levels are not consistently tracked across production, transport, and storage, increasing the probability of negative incidences. Respondents further warned that poor information sharing across the food production system hinders efforts to assure food safety and supply assurance.

Similarly, managers often talked about how difficult it is to find qualified and experienced employees. Specific education/training programs applicable to the food industry-e.g., farm operations, production at all levels, livestock storage and care-are rare and under-capacitated. Most employees are thus self-educated via on-the-job experience-a reality that perpetuates counterproductive attitudes, perceptions, and behaviors. Much of the existing workforce, thus, lacks the skills to fully integrate automated technology into the food production system. The lack of investment in technology and worker skills means that Turkish food production and delivery systems cannot secure safe and reliable farm-to-fork supply chains. The added risks and costs of organic, non-GMO, and responsibly raised livestock simply push sustainability further out of reach.

\subsubsection{Systems Design Risks}

Managers consistently lamented that food production and delivery supply chains are very complex, interconnected systems (see Table 8). They emphasized that very few, if any, managers really understand how the entire systems works. As a result, no one really knows how a decision made in one area will affect the entire system. Socially responsible practice simply increases complexity. For instance, seasonal variations in temperature impact every facet of food production from raising stock/crops to bringing the product to market. Keeping the cold chain under control is a persistent challenge. As diverse stakeholders possess differing perspectives or competing interests, a coordinated supply chain response is difficult. For example, not everyone is willing to invest in the advanced technologies that increase control, reduce risk, and enable higher levels of sustainable practice. Longer, more geographically-dispersed supply chains with numerous handling points are particularly susceptible to disruption since a failure at any point threatens sustainability across the entire chain. To better manage multi-level interdependencies and achieve higher levels of social responsibility, systems design, including supplier selection, needs to make interdependencies and tradeoffs visible, a risk-mitigation practice that requires high-level skills and increases cost.

Table 8. Quotes for systems design risk dimension.

\begin{tabular}{|c|c|c|}
\hline Risk Factor & Power Quote & Proof Quote \\
\hline $\begin{array}{l}\text { Environmental Conditions: Any } \\
\text { risk factor associated with larger } \\
\text { external forces addressing a failure } \\
\text { or negativity of a system effect }\end{array}$ & $\begin{array}{l}\text { "Supply chain risks resulting from } \\
\text { environmental factors are also relevant here. } \\
\text { During a global downturn or terrorism, you } \\
\text { are subject to market and price risks ...". } \\
\text { "For example, Bulgaria closed its customs } \\
\text { because of documentation issues. Our } \\
\text { vehicles waited } 3 \text { days. It is a big cost to us. }\end{array}$ & $\begin{array}{l}\text { "We depend on imports in the } \\
\text { feed industry". "When you work } \\
\text { with a single supplier, there are } \\
\text { risks of dependence". "Natural } \\
\text { disasters are big risks, especially } \\
\text { in agriculture and livestock. }\end{array}$ \\
\hline
\end{tabular}


Table 8. Cont.

\begin{tabular}{|c|c|c|}
\hline Risk Factor & Power Quote & Proof Quote \\
\hline $\begin{array}{l}\text { Structural Issues: Any risk factor } \\
\text { caused by internal or external } \\
\text { structures of supply chains }\end{array}$ & $\begin{array}{l}\text { "The biggest danger is subcontractors; e.g., } \\
\text { subcontracted dealers might sell out-of-date } \\
\text { products. We experience that a lot". } \\
\text { "Distance is risky in my opinion. Production } \\
\text { facilities should be as close to the customers } \\
\text { as possible". "The reason why it cannot } \\
\text { keep up with change and be flexible is that } \\
\text { the supply chain is a part of so many other } \\
\text { chains, with several members". }\end{array}$ & $\begin{array}{l}\text { "The biggest danger is } \\
\text { outsourcing". "... The longer the } \\
\text { chain, the harder it is ...". }\end{array}$ \\
\hline $\begin{array}{c}\text { Stakeholder-caused Difficulties: } \\
\text { Any risk factor caused by } \\
\text { stakeholder activities and } \\
\text { reliability }\end{array}$ & $\begin{array}{l}\text { "The first and last link of the chain: the } \\
\text { biggest dangers are happening there". "The } \\
\text { biggest risk is the last sales point in the } \\
\text { market, I mean markets, shops, etc. where } \\
\text { the cold chain ends. They are not protecting } \\
\text { the cold chain sufficiently". "It is very } \\
\text { important to work with stakeholders that } \\
\text { we believe perform well". }\end{array}$ & $\begin{array}{l}\text { "The riskiest group is the grocery } \\
\text { stores, the restaurants: the last } \\
\text { point". "Your carrier has to } \\
\text { transport without one mistake to } \\
\text { not break the cold chain". }\end{array}$ \\
\hline $\begin{array}{l}\text { Seasonal Climate Conditions: Any } \\
\text { risk factor associated with } \\
\text { seasonal variations }\end{array}$ & $\begin{array}{l}\text { "There is cold storage in airports ... but in } \\
\text { places with temperatures of } 45-50^{\circ} \mathrm{C} \text {, } \\
\text { sometimes there are de-icing incidences". } \\
\text { "Milk can vary widely depending on the } \\
\text { season. For example, the temperature you } \\
\text { ferment the yogurt or cheese in summer is } \\
\text { different from the temperature you ferment } \\
\text { the yogurt in winter. Even southwest winds } \\
\text { immediately affect the milk's quality". }\end{array}$ & $\begin{array}{l}\text { "The risk is more in summer". } \\
\text { "Seasonal changes create } \\
\text { problems". "We increase the salt } \\
\text { ratio on fish in summer ... or it } \\
\text { melts ...". }\end{array}$ \\
\hline
\end{tabular}

To summarize, the interviews clearly show that the interaction between sustainability and risk is multi-faceted and nuanced. The sheer number of risk dimensions (not to mention the number of potential risks within each dimension) introduce a great deal of detail complexity. This detail complexity confounds managerial decision-making. Managers thus struggle to understand the nature of the sustainability/risk challenge in food production systems. Facing intense cost pressure and seeking short-term results, managers can feel overwhelmed, making it easier to accept sub-optimal social responsibility and to ignore, rather than mitigate risks. This behavioral reality suggests the following propositions for future research.

Proposition 1. Ignoring sustainability-induced risks, and their costs, may make it easier to justify the emergent costs of sustainability programs. But, this behavior exposes the firm to higher, more consequential costs.

Proposition 2. The extent to which managers can identify and mitigate sustainability-induced risks, reduces the overall cost of sustainability programs, enhancing their long-term viability.

Proposition 3. Sustainability-induced risks should be analyzed from a holistic systems perspective so that tradeoffs and constraints can be analyzed. Such analysis is needed to avoid the unintended consequences of risk-mitigation initiatives.

Proposition 4. Prioritizing behavioral risks enables managers to change sustainability's risk profile, multiplying the return on investment in risk mitigation efforts. The goal is to reduce both the immediate costs of risk mitigation and the long-term costs of sustainability programs.

\section{Conclusions and Contributions}

Sustainability is becoming a strategic imperative across the world's affluent economies. Yet, despite customers' expressed desires to consume more sustainable products and buy from sustainable 
companies, they remain reluctant to pay more for sustainability. The result: companies struggle to justify sustainability's higher costs. Thus, progress toward lower carbon footprints and more sustainable products remains slow. Demonstrating a positive return on investment in emerging economies-where consumers lack discretionary spending power-is especially difficult. Not only are increased revenues depressed, but costs are often higher.

As summarized in Table 9, our research findings suggest that one cost category that is likely higher in emerging economies is the costs of sustainability-induced risks. These added costs manifest in two forms. Specifically, if a company recognizes the risks, up-front investments can be made to mitigate, or entirely eliminate, the risks. Unfortunately, these initial investments increase the costs of sustainability programs, reducing projected returns and making it harder to justify sustainability investments. Alternatively, if managers ignore sustainability-induced risks-something that is easy to do for unknown-unknown risks - the probability of a supply shortage or a food safety incident increases. If a disruption occurs, returning operations to normal can be very expensive. In either scenario, sustainability-induced risks can be a make-or-break factor in assessing the viability of sustainability.

Table 9. Summary of research questions and findings.

\begin{tabular}{ll}
\hline \multicolumn{1}{c}{ Research Question } & \multicolumn{1}{c}{ Findings } \\
\hline $\begin{array}{l}\text { Does sustainability introduce new and unexpected } \\
\text { risks into food supply chains? }\end{array}$ & $\begin{array}{l}\text { We found 61 distinct risk elements, which compose five } \\
\text { theoretical risk dimensions. }\end{array}$ \\
\hline $\begin{array}{l}\text { If so, what is the nature of these } \\
\text { sustainability-induced risks? }\end{array}$ & $\begin{array}{l}\text { Sustainability-induced risks are embedded in employee } \\
\text { behavior, influencing not just systems design, but also } \\
\text { organizational and food safety routines. }\end{array}$ \\
\hline $\begin{array}{l}\text { How do sustainability and risk interact to influence } \\
\text { managerial decision making and ultimately the } \\
\text { viability of sustainability programs? }\end{array}$ & $\begin{array}{l}\text { Sustainability-induced risks raise both actual and potential } \\
\text { costs. Managers, however, tend to ignore many of these } \\
\text { risks, increasing the likelihood of disruption. }\end{array}$ \\
\hline
\end{tabular}

\subsection{Theoretical Implications}

This study's findings ground important theoretical implications, identifying new directions for research to help improve the long-term viability of sustainability initiatives. For instance, the findings document how inseparably connected sustainability and risk are in food production systems. Sustainability is not just a response designed to mitigate reputational risks. Rather, sustainability changes organizational and traceability routines, introducing behavioral and operating risks. That is, decisions related to promoting food safety and sustainable supply always impact risk conditions, changing the cost equation for sustainable food production systems.

Since numerous behavioral and operating risks are introduced, managers need to take the interaction among risk factors into consideration and proactively mitigate their root causes. This holistic approach will help prioritize risk-mitigation investments and help avoid counterproductive results.

Mapping the inter-relationships among risk dimensions may clarify the risk interactions. Clearly, behavioral risks must be addressed at the outset of sustainability planning. Ultimately, any reduction in behavioral risks promulgates improvements across other sustainability-induced risks.

Finally, behavioral research has long been the domain of sociology and or psychology. More recently, other disciplines have recognized the promise of behavioral research-thus, the emergence of behavioral economics, finance, and accounting. Behavioral supply chain research is in its infancy. This reality is intriguing in that extant academic research has largely overlooked behavior's role as an inhibitor to effective risk mitigation and sustainability implementation success. That is, what managers implicitly recognize as important and what academics research diverges. This reality makes it more difficult to identify ways to mitigate risk and enhance the viability of food system sustainability projects. The time has come to close the gap between what academics study and what managers must learn to do. 


\subsection{Managerial Implications}

The findings also inform managerial action. First, managers need to recognize the interaction between sustainability and risk and begin to include conscious risk-mitigation discussions in the earliest stages of sustainability design. Simply put, sustainability and risk management programs must be integrated to develop a common agenda capable of mitigating the negative influence emerging from their interaction. Otherwise, the costs of unmitigated risks will continue to undermine the viability of the sustainability programs.

Second, greater effort and investment should be targeted to a company's human resource development to cultivate the right mindset and inculcate the skills needed to effectively pursue sustainable food production system. Absent these investments, bounded rationality will perpetuate counterproductive behaviors, exacerbating risk and undermining sustainability. Behavior-based management helps to mitigate food-production risks as it focuses on processes that drive and determine outcomes.

Third, behavior-focused training and measurement can help companies productively manage the extended food production supply chain. By promoting risk-mitigation and sustainability know-how across the supply chain, overall system costs can be reduced, removing a key reason why upstream suppliers resist many sustainability programs [68]. As supply-chain-wide costs of sustainability programs decline, more companies will anxiously engage in cleaner production. Such an outcome is important to avoid the systems effect of risk factors; that is, to avoid any risk factor at any stage of the supply chain from threatening the latter stages with greater impact on the sustainability of the entire chain.

Fourth, the research reported here reveals that sustainability-induced risks are prevalent and pervasive in food supply chains. Emerging market attitudes and behaviors embed and exacerbate risks across almost all organizational and value-added systems. These pervasive attitudes and behaviors introduce and perpetuate a variety of risks. The dynamic complexity that results makes diagnosis—and, therefore, prescription-more difficult than if risk categories were independent.

Figure 3, therefore, depicts a model to ensure continuous assessment and mitigation of sustainability-induced risk factors at all levels. The model is simple, actionable, and comprehensive-requirements to facilitate implementation in emerging economies and other resource-constrained settings. Specifically, key informants related how decision makers in food production systems and their extended supply chains routinely break food safety norms, triggering numerous unknown risks and higher sustainability costs. Bounded rationality that results from a lack of knowledge, information, and training promotes continuation of counterproductive practices [69], threatening the long-term viability of sustainability efforts in the food industry.

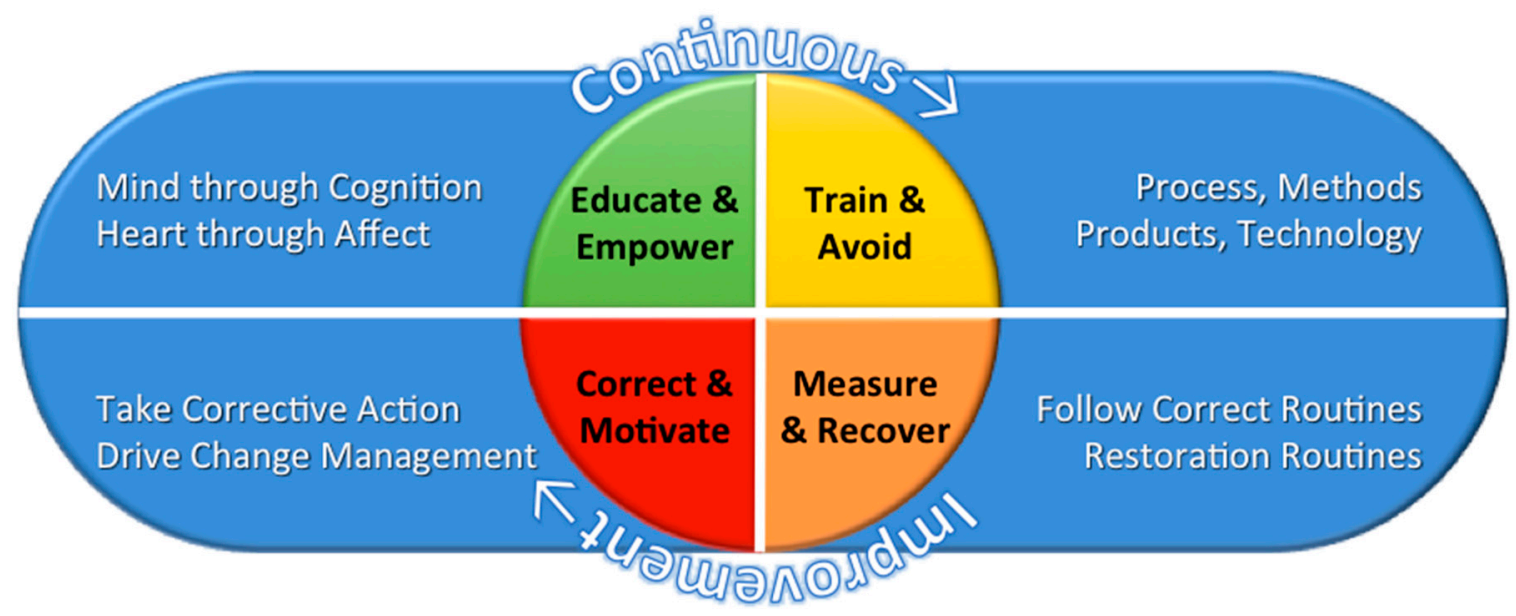

Figure 3. A model to mitigate sustainability-induced behavioral risks. 
The model begins with fundamental education, which ideally should begin in childhood to change awareness and create cognition. Education must be followed by job-based training that focuses on processes, products, methods, and technology. To leverage sustainability over time, secondary training should enhance contingency and change management skills. The reality is that people's behavioral characteristics and approach to both risk and sustainability are shaped by their interests, preferences, and capabilities [70].

Carefully designed measurement must reinforce appropriate and proactive behavior. Indeed, measurement is critical to managing complex, holistic systems, like the sustainability-induced risk interaction delineated by this research. Critically, measurement provides key insight into the inter-relationships among the diverse elements of complex food production systems [71]. Thus, measurement precedes the effective corrective action that addresses and eliminates the underlying causes of sustainability-induced risks, preventing their recurrence. Ultimately, it is important to motivate an ongoing effort to systematically improve the entire sustainability-risk interaction by overcoming inertia and driving change [72].

Ultimately, the research demarcates a sustainability-risk vicious cycle. Sustainability induces risks. Risks increase costs. Higher costs undermine the viability of sustainability. Importantly, the research also uncovered a risk-mitigation decision tradeoff. Recognizing sustainability-induced risks and proposing mitigation efforts raises the costs of sustainability. Ignoring risks increase the probability of costly disruptions. The research suggests that, by better understanding the nature of the sustainability-risk interaction and targeting the superordinate risk dimension-that is, the behavioral dimension-managers can proactively alleviate the vicious cycle.

\subsection{Limitations and Directions for Further Research}

Like all research, this study has limitations, which open opportunities for future research. First, this research is industry-specific, focusing on the food production system. Extending the research to other industries will document how sustainability-risk interaction vary and threaten to undermine sustainability's long-term viability. Second, more insight into the sustainability-risk vicious cycle is also needed. Third, the decision strategies, risk environment, and sustainability practices of private companies are likely to differ from those of publicly-owned firms. Therefore, future work could usefully investigate publicly-owned, as well as private, companies. Fourth, the superordinate nature of behavior risks suggests that behavioral experiments be used to evaluate tradeoffs across the integrated sustainability-risk interaction. Finally, future studies should explore certain sustainability-induced food supply chain risk factors in more depth, especially consciousness and complacency, self-focus, ethics, opportunism, and inertia, which are largely unexplored in the literature. Similarly, cost concerns of supply chain partners, which lead to opportunistic behaviors, are important threats to be considered.

Author Contributions: A.G. originated this research and collected all of the data as part of her dissertation. O.T., the dissertation advisor, provided guidance throughout the development of the dissertation. S.E.F. helped contextualize the paper, develop the theory, and interpret the results. All authors contributed to this work.

Funding: The research received no external funding.

Conflicts of Interest: The authors declare no conflicts of interest. 


\section{Appendix}

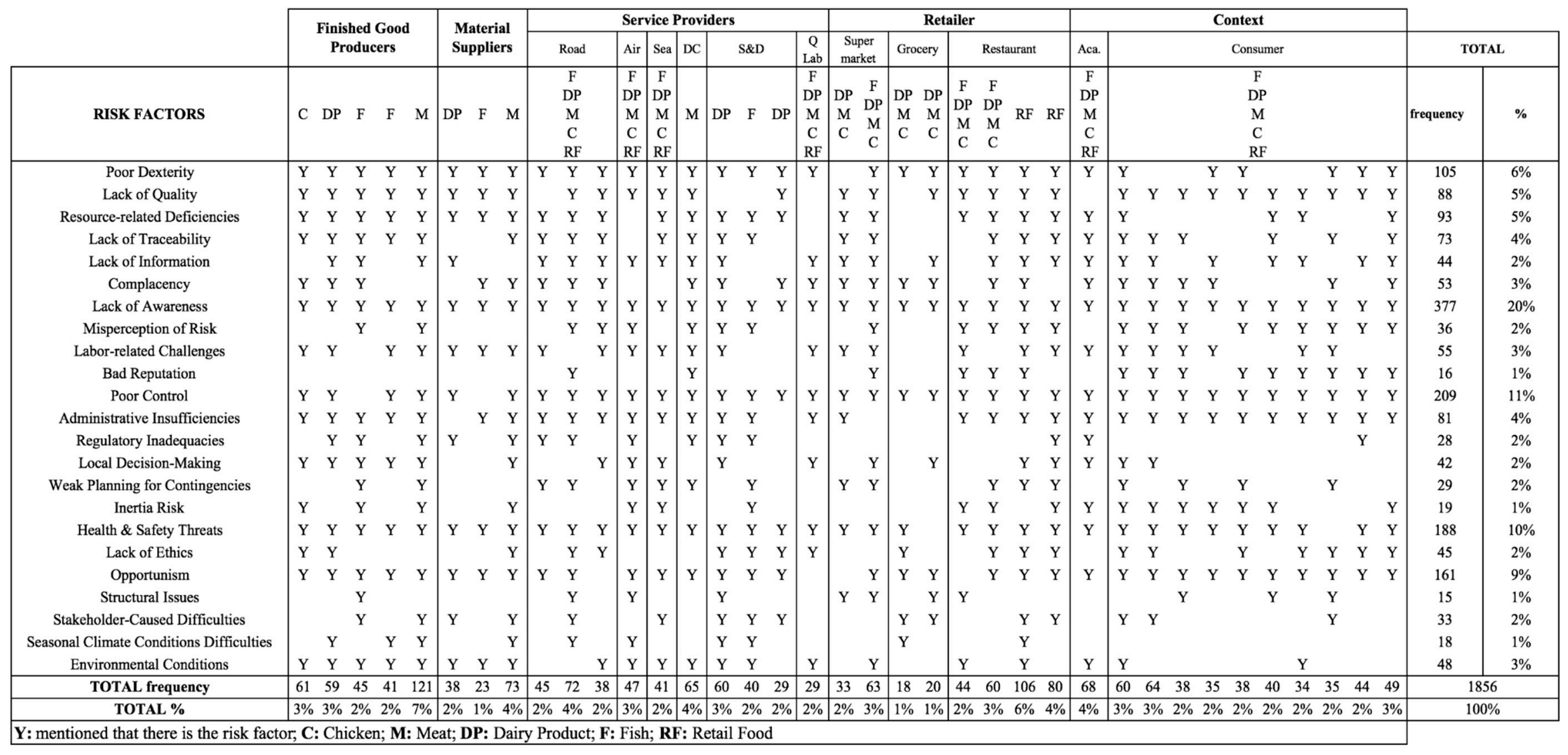




\section{References}

1. Elkington, J. Cannibals with Forks: The Triple Bottom Line of 21st Century; Capstone Publishing Ltd.: Oxford, UK, 1997.

2. Fawcett, S.E.; Brockhaus, S.; Knemeyer, A.M.; Fawcett, A.M. Sustainability as strategy: Caught in the luxury trap. Supply Chain Manag. Rev. 2015, 19, 16-25.

3. Brockhaus, S.; Fawcett, S.E.; Knemeyer, A.M.; Fawcett, A.M. Motivations for environmental and social consciousness: Reevaluating the sustainability-based view. J. Clean. Prod. 2017, 143, 933-947. [CrossRef]

4. O'Callaghan, T. Disciplining multinational enterprises: The regulatory power of reputation risk. Glob. Soc. 2007, 21, 95-117. [CrossRef]

5. Ganesan, S.; George, M.; Jap, S.; Palmatier, R.W.; Weitz, B. Supply chain management and retailer performance: Emerging trends, issues, and implications for research and practice. J. Retail. 2009, 85, 84-94. [CrossRef]

6. Ko, E.; Hwang, Y.K.; Kim, E.Y. Green marketing'functions in building corporate image in the retail setting. J. Bus. Res. 2013, 66, 1709-1715. [CrossRef]

7. Godfrey, P.C.; Merrill, C.B.; Hansen, J.M. The relationship between corporate social responsibility and shareholder value: An empirical test of the risk management hypothesis. Strateg. Manag. J. 2009, 30, 425-445. [CrossRef]

8. Gladwin, T.N.; Kennelly, J.J.; Krause, T.S. Shifting paradigms for sustainable development: Implications for management theory and research. Acad. Manag. Rev. 1995, 20, 874-907. [CrossRef]

9. Hofmann, H.; Busse, C.; Bode, C.; Henke, M. A foundation of sustainability related supply chain risks in stakeholder theory. In Efficiency and Logistics; Springer: Berlin/Heidelberg, Germany, 2013; pp. 185-196.

10. Anderson, D.R.; Anderson, K.E. Sustainability risk management. Risk Manag. Insur. Rev. 2009, 12, 25-38. [CrossRef]

11. Hofmann, H.; Busse, C.; Bode, C.; Henke, M. Sustainability-related supply chain risks: Conceptualization and management. Bus. Strategy Environ. 2014, 23, 160-172. [CrossRef]

12. Carter, C.R.; Rogers, D.S. A framework of sustainable supply chain management: Moving toward new theory. Int. J. Phys. Distrib. Logist. Manag. 2008, 38, 360-387. [CrossRef]

13. Carter, C.R.; Liane Easton, P. Sustainable supply chain management: Evolution and future directions. Int. J. Phys. Distrib. Logist. Manag. 2011, 41, 46-62. [CrossRef]

14. Singhal, P.; Agarwal, G.; Mittal, M.L. Supply chain risk management: Review, classification and future research directions. Int. J. Bus. Sci. Appl. Manag. 2011, 6, 15-42.

15. Hassini, E.; Surti, C.; Searcy, C. A literature review and a case study of sustainable supply chains with a focus on metrics. Int. J. Prod. Econ. 2012, 140, 69-82. [CrossRef]

16. Seuring, S.; Müller, M. From a literature review to a conceptual framework for sustainable supply chain management. J. Clean. Prod. 2008, 16, 1699-1710. [CrossRef]

17. Luo, J.; Ji, C.; Qiu, C.; Jia, F. Agri-food supply chain management: Bibliometric and content analyses. Sustainability 2018, 10, 1573. [CrossRef]

18. Taylor, K. Chipotle's Stock Is down after Claims of Food-Poisoning Incidents in Manhattan. Available online: http:/ / www.businessinsider.com/chipotles-stock-down-after-reports-of-another-food-poisoning2016-7 (accessed on 15 September 2016).

19. Krysiak, F.C. Risk management as a tool for sustainability. J. Bus. Ethics 2009, 85, 483-492. [CrossRef]

20. Prakash, S.; Soni, G.; Rathore, A.P.S. A critical analysis of supply chain risk management content: A structured literature review. J. Adv. Manag. Res. 2017, 14, 69-90. [CrossRef]

21. Ho, W.; Zheng, T.; Yildiz, H.; Talluri, S. Supply chain risk management: A literature review. Int. J. Prod. Res. 2015, 53, 5031-5069. [CrossRef]

22. Rangel, D.A.; de Oliveira, T.K.; Leite, M.S.A. Supply chain risk classification: Discussion and proposal. Int. J. Prod. Res. 2015, 53, 6868-6887. [CrossRef]

23. Song, W.; Ming, X.; Liu, H.C. Identifying critical risk factors of sustainable supply chain management: A rough strength-relation analysis method. J. Clean. Prod. 2017, 143, 100-115. [CrossRef]

24. Giannakis, M.; Papadopoulos, T. Supply chain sustainability: A risk management approach. Int. J. Prod. Econ. 2016, 171, 455-470. [CrossRef] 
25. Jüttner, U. Supply chain risk management: Understanding the business requirements from a practitioner perspective. Int. J. Logist. Manag. 2005, 16, 120-141. [CrossRef]

26. Olson, D.L.; Wu, D.D. A Review of Enterprise Risk Management in Supply Chain. Kybernetes 2010, 39, 694-706. [CrossRef]

27. Wolf, J. Sustainable supply chain management integration: A qualitative analysis of the german manufacturing industry. J. Bus. Ethics 2011, 102, 221-235. [CrossRef]

28. Barreto, I. Dynamic capabilities: A review of past research and an agenda for the future. J. Manag. 2010, 36, 256-280. [CrossRef]

29. Churchman, C. The Systems Approach; West: West Whiteland Township, PA, USA; Delta: Atlanta, GA, USA, 1968.

30. Gammelgaard, B. The Systems Approach in Logistics; Institute for Logistics and Transport, Copenhagen Business School: Frederiksberg, Denmark, 1997; pp. 9-20.

31. Senge, P.M. The Fifth Discipline: The Art and Practice of the Learning Organization; Broadway Business: New York, NY, USA, 2006.

32. Cooper, M.C.; Lambert, D.M.; Pagh, J.D. Supply chain management: More than a new name for logistics. Int. J. Logist. Manag. 1997, 8, 1-14. [CrossRef]

33. Warren, K.; Franklin, C.; Streeter, C.L. New directions in systems theory: Chaos and complexity. Soc. Work 1998, 43, 357-372. [CrossRef]

34. Choi, T.Y.; Dooley, K.J.; Rungtusanatham, M. Supply networks and complex adaptive systems: Control versus emergence. J. Oper. Manag. 2001, 19, 351-366. [CrossRef]

35. Pathak, S.D.; Day, J.M.; Nair, A.; Sawaya, W.J.; Kristal, M.M. Complexity and adaptivity in supply networks: Building supply network theory using a complex adaptive systems perspective. Decis. Sci. 2007, 38, 547-580. [CrossRef]

36. Wilding, R.D. Chaos theory: Implications for supply chain management. Int. J. Logist. Manag. 1998, 9, 43-56. [CrossRef]

37. Tetenbaum, T.J. Shifting paradigms: From Newton to chaos. Organ. Dyn. 1998, 26, 21-32. [CrossRef]

38. Giammona, C.; Patton, L. Chipotle's Biggest Strength Is Suddenly Its Biggest Weakness. Available online: http:/ / www.bloomberg.com/news/articles/2015-12-08/chipotle-s-greatest-strength-is-now-its-greatestweakness-too (accessed on 15 September 2016).

39. Goldratt, E.M.; Cox, J. The Goal: Excellence in Manufacturing; North River Press: Croton-on-Hudson, NY, USA, 1984.

40. Fawcett, S.E.; Pearson, J.N. Understanding and applying constraint management in today's manufacturing environments. Prod. Inventory Manag. J. 1991, 32, 46.

41. Spencer, M.S.; Cox, J.F. Optimum production technology (OPT) and the theory of constraints (TOC): Analysis and genealogy. Int. J. Prod. Res. 1995, 33, 1495-1504. [CrossRef]

42. Blackstone, J.H. Theory of constraints-A status report. Int. J. Prod. Res. 2010, 39, 1053-1080. [CrossRef]

43. Rahman, S.U. The theory of constraints' thinking process approach to developing strategies in supply chains. Int. J. Phys. Distrib. Logist. Manag. 2002, 32, 809-828. [CrossRef]

44. Fawcett, S.E.; Fawcett, A.M.; Watson, B.J.; Magnan, G.M. Peeking inside the black box: Toward an understanding of supply chain collaboration dynamics. J. Suppl. Chain Manag. 2012, 48, 44-72. [CrossRef]

45. Mentzer, J.T.; DeWitt, W.; Keebler, J.S.; Min, S.; Nix, N.W.; Smith, C.D.; Zacharia, Z.G. Defining supply chain management. J. Bus. Logist. 2001, 22, 1-25. [CrossRef]

46. Yin, R.K. Case Study Research: Design and Methods, 4th ed.; Sage publications Inc.: Thousand Oaks, CA, USA, 2009.

47. Creswell, J.W. Qualitative Inquiry and Research Design: Choosing among Five Approaches; Sage publications: Thousand Oaks, CA, USA, 2007.

48. Sheth, J.N. Impact of emerging markets on marketing: Rethinking existing perspectives and practices. J. Mark. 2011, 75, 166-182. [CrossRef]

49. Jia, F.; Zuluaga, L.; Bailey, A.; Rueda, X. Agricultural supply chain management in emerging economies: A review of literature. J. Clean. Prod. 2018, 189, 263-278. [CrossRef]

50. Rapoza, K. 19 Reasons Why Emerging Markets belong in Your Portfolio. Available online: https://www. forbes.com/sites/kenrapoza/2011/07/08/emerging-markets-coke-vale-baidu-petrobras-ishares/2011 (accessed on 15 September 2016). 
51. Silvestre, B.S. A hard nut to crack! Implementing supply chain sustainability in an emerging economy. J. Clean. Prod. 2015, 96, 171-181. [CrossRef]

52. Eren-Erdogmus, I.; Cobanoglu, E.; Yalcın, M.; Ghauri, P.N. Internationalization of emerging market firms: The case of Turkish retailers. Int. Mark. Rev. 2010, 27, 316-337. [CrossRef]

53. Ozsomer, A.; Bodur, M.; Cavusgil, S.T. Marketing standardisation by multinationals in an emerging market. Eur. J. Mark. 1991, 25, 50-64. [CrossRef]

54. Rajurkar, S.W.; Jain, R. Food supply chain management: Review, classification and analysis of literature. Int. J. Integr. Suppl. Manag. 2011, 6, 33-72. [CrossRef]

55. Akkerman, R.; Farahani, P.; Grunow, M. Quality, safety and sustainability in food distribution: A review of quantitative operations management approaches and challenges. OR Spectr. 2010, 32, 863-904. [CrossRef]

56. Cavinato, J.L. Supply chain logistics risks: From the back room to the board room. Int. J. Phys. Distrib. Logist. Manag. 2004, 34, 383-387. [CrossRef]

57. Wognum, P.N.; Bremmers, H.; Trienekens, J.H.; van der Vorst, J.G.; Bloemhof, J.M. Systems for sustainability and transparency of food supply chains-current status and challenges. Adv. Eng. Inform. 2011, 25, 65-76. [CrossRef]

58. Eisenhardt, K.M. Building theories from case study research. Acad. Manag. Rev. 1989, 14, 532-550. [CrossRef]

59. Fawcett, S.E.; Waller, M.A.; Miller, J.W.; Schwieterman, M.A.; Hazen, B.T.; Overstreet, R.E. A trail guide to publishing success: Tips on writing influential conceptual, qualitative, and survey research. J. Bus. Logist. 2014, 35, 1-16. [CrossRef]

60. Pettigrew, A.M. Longitudinal field research on change: Theory and practice. Organ. Sci. 1990, 1, $267-292$. [CrossRef]

61. Houghton, J.R.; Rowe, G.; Frewer, L.J.; Van Kleef, E.; Chryssochoidis, G.; Kehagia, O.; Korzen-Bohr, S.; Lassen, J.; Pfenning, U.; Strada, A. The quality of food risk management in Europe: Perspectives and priorities. Food Policy 2008, 33, 13-26. [CrossRef]

62. Locke, K. Grounded Theory in Management Research; Sage: Newcastle upon Tyne, UK, 2001.

63. Pratt, M.G. Fitting oval pegs into round holes: Tensions in evaluating and publishing qualitative research in top-tier North American journals. Organ. Res. Methods 2008, 11, 481-509. [CrossRef]

64. Miles, M.B.; Huberman, A.M. Qualitative Data Analysis: An Expanded Sourcebook; Sage: Newcastle upon Tyne, UK, 1994.

65. Haavisto, I.; Kovács, G. Perspectives on sustainability in humanitarian supply chains. Dis. Prev. Manag. Int. J. 2014, 23, 610-631. [CrossRef]

66. Seuring, S.; Gold, S. Conducting content-analysis based literature reviews in supply chain management. Suppl. Chain Manag. Int. J. 2012, 17, 544-555. [CrossRef]

67. Williamson, O.E. Markets and Hierarchies; Free Press: New York, NY, USA, 1975.

68. Brockhaus, S.; Fawcett, S.E.; Kersten, W.; Knemeyer, A.M. A framework for benchmarking product sustainability efforts: Using systems dynamics to achieve supply chain alignment. Benchmarking Int. J. 2016, 23, 127-164. [CrossRef]

69. Hirschauer, N.; Bavorová, M.; Martino, G. An analytical framework for a behavioural analysis of non-compliance in food supply chains. Br. Food J. 2012, 114, 1212-1227. [CrossRef]

70. Bachev, H. Risk management in the agri-food sector. Contemp. Econ. 2013, 7, 45-62. [CrossRef]

71. Morioka, S.N.; Carvalho, M.M. Measuring sustainability in practice: Exploring the inclusion of sustainability into corporate performance systems in Brazilian case studies. J. Clean. Prod. 2016, 136, 123-133. [CrossRef]

72. Engert, S.; Rauter, R.; Baumgartner, R.J. Exploring the integration of corporate sustainability into strategic management: A literature review. J. Clean. Prod. 2016, 112, 2833-2850. [CrossRef]

(C) 2018 by the authors. Licensee MDPI, Basel, Switzerland. This article is an open access article distributed under the terms and conditions of the Creative Commons Attribution (CC BY) license (http:/ / creativecommons.org/licenses/by/4.0/). 